\title{
Mental health risk factors during COVID-19 pandemic in the Polish population
}

\section{Authors' full name}

Pavel M. Larionov, Kazimierz Wielki University, Faculty of Psychology, Bydgoszcz, Poland, pavel@ukw.edu.pl

Karolina Mudło-Głagolska, Kazimierz Wielki University, Faculty of Psychology, Bydgoszcz, Poland, karolina.glagolska@gmail.com

\section{Correspondence}

Pavel M. Larionov, Kazimierz Wielki University, Faculty of Psychology, L. Staffa 1, Bydgoszcz, Poland (telephone: + 48 523708432; e-mail: pavel@ukw.edu.pl).

\section{Funding Statement}

This research received no specific grant from any funding agency, commercial or not-for-profit sectors.

\section{Authors' contributions}

The authors jointly wrote the manuscript and read and confirmed the final version.

\section{Funding}

Not applicable.

\section{Competing interests}

The authors declare that they have no competing interests. 
Background: The level of post-traumatic stress symptoms (PTSS) associated with the COVID-19 outbreak, stress, anxiety and depressive symptoms was assessed. Risk factors for mental health in the Polish population have been identified.

Methods: The 926 respondents completed a set of questionnaires consisting of questions concerning COVID-19, PTSS related to the COVID-19 outbreak (Impact of Event Scale-Revised, IES-R) and their mental health status (Depression, Anxiety and Stress Scale, DASS-21).

Results: Most respondents reported severe PTSS related to the COVID-19 outbreak (44.06\%), normal intensity of depressive symptoms (52.38\%), anxiety symptoms (56.05\%) and stress (56.48\%). Female gender, parental status, having a relationship, at least a two-person household are associated with higher PTSS and DASS-21 subscale. A few physical symptoms, a medical visit, quarantine, negative health evaluation, and chronic diseases, knowledge of the increase in the number of infected people and the number of deaths are associated with higher levels of PTSS. Some of the precautions and the need for additional information on COVID-10, the certainty of a high probability of contracting COVID-19, a low survival rate and concerns about loved ones are associated with higher PTSS.

Conclusions: The indicated risk factors can be used to develop psychological interventions to improve mental health.

Keywords: coronavirus disease 2019 (COVID-19), stress, depressive symptoms, anxiety symptoms, post-traumatic stress symptoms.

\section{Introduction}

According to the World Health Organization (WHO), the most significant psychological effects of the COVID-19 pandemic are increased levels of stress and anxiety [1]. The WHO emphasises that an increase in loneliness, depression, alcohol, and drug abuse as well as self-harm or suicidal behaviour may be observed in the nearest future [1]. Social isolation and quarantine have positive effects on the epidemiological situation, but are negative for mental health [2]. The situation is aggravated by social stigma related to COVID-19 [3].

In China, research has been conducted regarding psychosocial functioning and the identification of risk groups in the general population. Huang and Zhao in the study of a sample of 7236 people showed that the percentages of anxiety, depression, and poor quality sleep were $35.1 \%, 20.1 \%$, and $18.2 \%$ respectively [4]. No statistically significant differences were found in the level of anxiety, depression 
and sleep quality between men and women. The influence of age on the occurrence of anxiety and depressive symptoms was observed. It turned out that young people up to 35 years of age reported these symptoms more often than people over 35 years of age. The focus on information about COVID19 of more than three hours a day led to an increased level of anxiety symptoms. Healthcare workers were characterized by high levels of anxiety, depression, and poor sleep quality compared to other professions [4]. Sun et al. indicated that female gender, close contact with COVID-19 infected patients, living in cities with large numbers of infections and sleep problems were risk factors for severe posttraumatic stress disorder. There was no impact of age and education on the development of PTSS [5]. Qian et al. [6] found that gender, age, education, work, and marital status are not statistically significantly related to the level of anxiety during the COVID-19 pandemic, while low economic status and a suspicion of infected cases in the neighbourhood as well as a disorientation caused by COVID-19 information significantly increase the level of anxiety. Wang, Di, Ye, and Wei confirmed that women were at greater risk of anxiety than men during the COVID-19 pandemic [7]. Education level and occupation were associated with depressive symptoms. Those with a bachelor's degree were less likely to be depressed than those with a master's or higher degree. Specialists were more likely to be at risk of depression than workers in the service sector and workers of other occupations [7]. In the United States, a study has been conducted which reported that a younger age and higher level of education are associated with a higher fear of SARS-CoV-2 coronavirus [8].

There is currently no evidence that the second wave of the COVID-19 pandemic will not occur in the near future. In times of uncertainty and instability, where security needs are much less met, the identification of risk factors of poor mental health during the pandemic and the identification of the most mentally vulnerable groups in society are important areas of research to develop credible psychological support programmes during the COVID-19 pandemic.

The aim of the study is to assess the posttraumatic stress symptoms (PTSS) associated with the COVID-19 outbreak, to determine the level of stress, anxiety, and depressive symptoms, and to identify risk factors for mental health in the Polish population. It is a replication of a study conducted in China by Wang et al. [9].

\section{Methods}

\section{Research participants}


The survey was completed by 926 people, $78.51 \%$ of whom are women. The average age of the respondents is 35.15 years $(\mathrm{SD}=12.53)$. The highest percentage of the respondents $(40.06 \%)$ live in large cities with more than 100 thousand inhabitants, followed by $23.76 \%$ living in rural areas, $22.89 \%$ in medium-sized cities up to 100 thousand inhabitants. The remaining people live in small towns up to 20 thousand inhabitants. Secondary education is held by $46.44 \%$, higher $-44.06 \%$, vocational $-6.59 \%$, and $2.92 \%$ of the respondents have primary education. Among the respondents, the highest percentage is married (43.09\%), then 30.13\% in an informal relationship, $19.01 \%$ are unmarried, 5.62\% are divorced and, 2.16\% are widows. Most of the respondents work professionally (54.75\%), 21.17\% are unemployed, people working and studying at the same time make up $11.45 \%$ of the sample, $6.37 \%$ are self-employed and taking care of children at home, $5.29 \%$ are retired, while $0.97 \%$ are students. A significant percentage of the respondents describe their socio-economic status as good (46.33\%), average $-39.09 \%$, very good $-10.69 \%$, bad $-3.33 \%$ and very bad $-0.54 \%$.

\section{Research tools}

The set of questionnaires used in the study corresponds to the one proposed by Wang et al. [9]. Polish adaptation of the Impact of Event Scale (IES-R) was used to determine the current PTSS caused by traumatic events [10]. The scale consists of 22 items and contains three subscales: (1) intrusion, which expresses recurring images, dreams, thoughts or perceptions associated with a traumatic event; (2) hyperarousal, characterized by increased vigilance, anxiety, impatience, difficulty in focusing attention, and (3) avoidance, manifested by efforts to get rid of thoughts, emotions or, conversations associated with a traumatic event. In this study, the value of Cronbach's $\alpha$ coefficient for the overall result is 0.73 . The Depression Anxiety Stress Scale (DASS-21) was developed by Lovibond and Lovibond [11]. The scale consists of 21 items, which are components of three subscales: depression, anxiety, and stress. The Depression scale assesses dysphoria, hopelessness, devaluation of life, self-deprecation, lack of interest/involvement, anhedonia, and inertia. The Anxiety scale assesses autonomic arousal, skeletal muscle effects, situational anxiety, and subjective experience of anxious affect. The Stress scale assesses difficulty relaxing, nervous arousal, and being easily upset/agitated, irritable/over-reactive, and impatient [11]. In this study, the value of Cronbach's $\alpha$ coefficient for the depression, anxiety, and stress subscale is $0.92,0.91,0.93$, and 0.97 for the overall result.

The survey was conducted within 14 days from 25 March 2020 to 7 April 2020 using the Google Forms platform.

\section{Statistical analysis}


Descriptive statistics have been calculated for socio-demographic data, physical symptoms and health care confidence, history of contact with infected objects, knowledge and concerns about COVID-19, precautionary measures against COVID-19 applied in the past 14 days and additional information required concerning COVID-19. The results of the IES-R and DASS-21 subscale have been expressed as an average and standard deviation. Linear regressions have been used to calculate one-dimensional correlations between socio-demographic data, physical symptoms and health care trust, history of contacts with infected objects, knowledge and concerns about COVID-19, precautionary measures aimed at COVID-19 in the past 14 days, additional information required concerning COVID-19 and the IES-S result, as well as the DASS-21 subscale. Two-tailed tests with a significance level of $\mathrm{p}<0.05$ have been applied. Statistical analysis has been conducted in Statistica 13.3.

\section{Results}

\section{Descriptive statistics}

Among the respondents, the highest percentage (44.06\%) are those with severe PTSS related to the COVID-19 outbreak. A normal level of PTSS is observed in $36.61 \%$ of the examined sample, in $13.17 \%$ - mild and moderate in $6.16 \%$ of respondents. The average result in the subscale of depression, anxiety, and stress is $35.89(S D=33.74)$. Among the respondents, 52.38\% show normal intensity of depressive symptoms, $15.98 \%$ - moderate and 10.37\% - mild. An extremely severe score of depressive symptoms concerned $14.25 \%$ of the respondents, while a severe $-7.02 \%$. In the subscale of anxiety in DASS-21, its normal level is shown by $56.05 \%$ of respondents, extremely severe anxiety $-20.62 \%$, $12.20 \%$ - moderate, $6.26 \%$ - severe, $4.86 \%$ - mild. In the group of respondents, $56.48 \%$ show normal stress intensity, moderate $-12.85 \%$, severe $-11.66 \%$, extremely severe $-9.61 \%$, and mild $-9.40 \%$.

\section{Socio-demographic characteristics}

Demographic characteristics are presented in Table 1. Male gender is significantly associated with lower IES-R scores and the DASS-21 stress and depression subscale. 18-20 years of age associated with lower IES-R score. Having a child is also associated with a higher IES-R score. Being single is associated with a significantly lower score in the IES-R scale, but a higher score in the DASS-21 scale of anxiety and depression. Informal relationships are associated with a higher score of anxiety and depressive symptoms. However, marriage is associated with a higher score in the depression subscale 
in DASS-21. A household consisting of at least two members is associated with a higher IES-R score. Detailed results are presented in Table 1.

\section{[Insert Table 1 about here]}

\section{Symptoms of COVID-19}

The percentage of various symptoms is presented in Table 2.

It is observed that the occurrence of chills, headache, myalgia, cough, breathing difficulty, dizziness, coryza, and sore throat are associated with a higher IES-R score.

[Insert Table 2 about here]

\section{Health status}

Clinic consultations and being put under quarantine by a health authority are shown to be associated with a higher IES-R score. Poor, very poor or average self-rated health status was significantly associated with a higher IES-R score. Chronic illness is also related to a higher IES-R score (Table 2).

\section{COVID-19 contact history}

The analysis shows that contact with a person with a COVID-19 suspicion or infected object is associated with a lower score of depressive symptoms (Table 3).

\section{[Insert Table 3 about here]}

\section{Knowledge about COVID-19}

Individuals who claimed that contact with infected objects is not a potential COVID-19 transmission route have a lower IES-R score and DASS-21 anxiety score. Knowledge of the increase in the number of infections and deaths is associated with a higher IES-R score. People who receive information through television have a higher IES-R score (Table 4).

[Insert Table 4 about here] 


\section{Concerns about COVID-19}

Those who had no confidence in their own doctor's ability to diagnose or recognize COVID-19 were significantly more likely to have higher scores in the IES-R scale.

A higher perceived likelihood of contracting COVID-19 was significantly associated with a higher IES$\mathrm{R}$ score. The strong belief of a high probability of survival for COVID-19 infection is associated with a lower IES-R score. Numerous concerns about the incidence of infection by relatives are associated with a higher IES-R score. Detailed results are presented in Table 4.

\section{Precautionary measures and additional health information required}

There is no correlation between covering the mouth while coughing and sneezing and the IES-R and DASS-21 results. Wearing a mask is associated with a lower anxiety score. Washing hands immediately after coughing, sneezing, or rubbing the nose was significantly associated with a higher IES-R score. Washing hands after touching polluted objects contributes to a lower DASS-21 depression score.

Staying at home from 0 to 9 hours due to COVID-19 is associated with a lower IES-R score and 10-19 hours a day spent at home is related to a lower score of DASS-21 subscale of anxiety.

Each aspect of the requirement for additional information on COVID-19 is linked to a higher IES-R score. The obtained results are presented in Table 5.

\section{[Insert Table 5 about here]}

\section{Discussion}

Respondents from Poland are characterized by a much higher average severity of stress, anxiety, and depressive symptoms and a slightly higher result of PTSS associated with the COVID-19 outbreak compared to the Chinese [9]. These results can probably be explained by the previous experience of the Chinese during the 2003 SARS-CoV epidemic, which was halted by syndromic surveillance, quarantine, and other methods that are now being widely used to stop the COVID-19 pandemic [12].

Almost every fifth respondent from Poland reported severe and extremely severe levels of stress, anxiety and depressive symptoms measured using the DASS-21 scale. The most serious case concerns depression, as every seventh respondent reported extremely severe depressive symptoms. To resolve the question about psychological support, it is important to conduct research to discover the psychological meaning of symptoms, which will make it possible to distinguish the content of 
problematic issues of mental health during the COVID-19 pandemic in various social groups. This is particularly important due to the serious effects of depressive symptoms for both psychological and economic reasons.

Psychological traumatisation is a natural process during the COVID-19 outbreak. Almost every second respondent from Poland is characterized by a severe PTSS caused by the COVID-19 breakout. A similar percentage is observed among the Chinese [9].

\section{The role of socio-demographic variables for mental health during a pandemic}

The study shows that male gender is significantly associated with lower scores in the DASS-21 stress scale and DASS-21 depression scale and PTSS related to the COVID-19 outbreak. A study in China also highlights that the female gender had a significantly higher risk of anxiety during the COVID-19 pandemic and H1N1 swine flu [7] and was at risk of posttraumatic stress [5, 13]. It indicates that women are less able to cope with psycho-emotional problems and are more likely to feel mental discomfort during the COVID-19 pandemic.

The study does not indicate the effect of age on stress, anxiety, and depressive symptoms. Only the age between 18-20 years is significantly associated with lower IES-R scores. Among the Chinese, no effect of age on stress, anxiety, and depressive symptoms and PTSS was also observed [5, 9]. However, other Chinese researchers have pointed out that young people between 18 and 30 years of age and people over 60 years of age experience a lot of psycho-emotional problems related to the COVID-19 pandemic [14]. Ahmed et al. noted that people aged 18 to 40 have more pronounced psychological problems associated with COVID-19, including alcohol consumption [15]. It turned out that age does not differentiate between the intensity of stress, anxiety, and depressive symptoms among Polish respondents.

Single and informal relationship status are significantly associated with a higher score in the DASS-21 scale of anxiety and depression. Being married is associated with a higher score in the DASS depression subscale.

The status of a parent is associated with higher scores on the IES-R scale of PTSS. The study clearly shows that as the number of people in the family (household) increases, the level of PTSS increases. This is probably related to the interaction of family members. Staying at home during social isolation and talking about COVID-19 in the family leads to an accumulation of the mental discomfort effect caused by the COVID-19 outbreak.

Unemployed people are characterised by higher levels of stress, anxiety, and depressive symptoms compared to people at work and students. This is probably due to a sense of economic danger. The 
development of psychological and economic support programmes for these people is particularly important to ensure public safety.

In summary, among the socio-demographic variables, gender, civil status, number of people in the household, parental, and professional status are important predictors of psycho-emotional problems, while age and education are not relevant.

\section{Health status influence on mental health during the pandemic}

All physical symptoms included in this study are directly related to COVID-19, which is likely to determine their particular significance in aggravating feelings of discomfort. The subjects, learning about the symptoms of COVID-19, pay more attention to them, which in effect may increase the risk of traumatisation. Compared to the original study [9], no association was found between the occurrence of

these symptoms and stress, anxiety, and depressive symptoms. It can be cautiously assumed that respondents from Poland are less mentally sensitive to the appearance of somatic symptoms compared to the Chinese.

A higher level of PTSS is associated with being in quarantine, having consulted a doctor in a medical clinic, assessing one' s health as poor or very poor, and average and chronic diseases. None of these variables is associated with the subscale of stress, anxiety, and depression in DASS-21. It is believed that the elderly and people with chronic diseases are at greater risk of severe COVID-19. Medical care services should pay special attention to the psychological functioning of people with these characteristics. It is particularly important that people at high risk feel more secure and do not give in to unnecessary adverse effects. The specificity of informing the public seems to be important for social behaviour.

In summary, the occurrence of some physical symptoms (chills, headache, myalgia, cough, breathing difficulty, dizziness, coryza, and sore throat) and being in quarantine, having consulted a medical doctor in a clinic, assessing health as poor or very poor and average and the presence of chronic diseases are significantly associated with a higher PTSS associated with the COVID-19 outbreak and are not significantly associated with stress, anxiety and depressive symptoms in DASS-21.

Hospitalisation, testing for COVID-19 as well as close or indirect contact with a COVID-19 infected individual or materials are not associated with the IES-R and DASS-21 scales (only contact with an individual with a COVID-19 suspicion or infected materials is associated with a lower depressive score in DASS-21).

The need for additional information on COVID-19 and mental health during COVID-19 
For almost $70 \%$ of Polish respondents, the main source of information on COVID-19 is the Internet (93.5\% among Chinese [9]), a significant percentage of them obtain information from television (almost 21\%). Receiving information from television is associated with higher IES-R scores. Seeking information on COVID-19 on TV is probably connected with watching news that appear regularly (every hour or more often). A person is less autonomous when choosing the content of the news and time of viewing than when deriving information from the Internet.

During a pandemic, the desire for additional information indicates the healthy position of citizens and concern for their health. In the case of respondents from Poland, there was no impact of the need for additional information concerning COVID-19 on the development of stress, anxiety, and depressive symptoms. The knowledge about the increase in the number of infected and the number of deaths is associated with a higher score in the IES-R scale. Regarding negative psycho-emotional symptoms, it is worth referring to the study by $\mathrm{Li}$ et al. [16], who noted that the perceived severity of COVID-19 was related to psycho-emotional problems, but paradoxically, it increased public participation in the prevention and precautionary measures.

The study shows that people who are distanced from the COVID-19 information and take COVID-19 with less seriousness experience less mental discomfort. However, it is important to determine whether these people will also take responsible precautions. In the case of people with low symptoms of mental trauma and high responsibility towards COVID-19, it is worth analysing what aspects of cognitive functioning provide an adequate approach towards COVID-19. Some reports were presented by Carvalho, Pianowski, and Gonçalves [17], who concluded that conscientiousness as a personality trait is positively associated with the recommended appropriate social distancing and frequent hand washing, and extraversion is negatively associated with maintaining certain principles of social distancing during the COVID-19 pandemic.

In conclusion, the need for additional information on COVID-19 is associated with a higher IES-R score for PTSS.

\section{Precautions and mental health during a pandemic}

At the time of the survey, the level of knowledge and the precautions taken can be considered as sufficiently high. From a psychological point of view, it can be noted that wearing masks as a previously unapplied precautionary measure has a twofold effect: on the one hand, wearing masks increases the level of psychological traumatisation, and on the other hand, it leads to a reduction in stress and anxiety symptoms. It is likely that the development of a sense of safety when wearing masks will help to reduce these symptoms. 
Almost two thirds of Polish respondents stayed at home between 20 and 24 hours a day, and almost every fourth respondent - 10-19 hours. The results of the survey show that the majority of Polish respondents have adapted to the ban on leaving home (lockdown) in addition to the permitted daily necessities. Staying at home from 0 to 9 hours a day is associated with a lower psychological impact of the outbreak.

It was not found that people under quarantine differ significantly in the severity of stress, anxiety, and depressive symptoms, but were characterized by a higher intensity of PTSS related to the COVID-19 outbreak. Neither the original study nor this one controlled the significant variable of quarantine time. In conclusion, almost all prevention measures are associated with higher PTSS associated with the COVID-19 outbreak.

\section{The link between concerns for COVID-19 and mental health during a pandemic}

The results of this study on concerns for COVID-19 are consistent with the results of a study conducted by $\mathrm{Xu}$ et al. [13] who concluded that concerns for the H1N1 pandemic are important predictors of PTSS in students . Similar conclusions are presented in the study, Wang et al. [9]. It is worth noting that in the Polish study there are no statistically significant associations between fear of infection and DASS-21 subscale in comparison with the original study by Wang et al. [9]. Lower or no concerns are associated with significantly lower levels of PTSS related to the COVID-19 outbreak. The belief that COVID-19 infection is very likely and survival in case of infection is not very probable is associated with an increased PTSS. It is likely that these relatively extreme positions can be described by means of self-control. The study Li, Yang, Dou, and Cheung [18] stresses that there is a link between perceived seriousness towards COVID-19 and mental health problems that are moderated by self-control. Individuals with low self-control are more vulnerable psychologically to COVID-19. Self-control is negatively correlated with mental health problems and the perceived severity of COVID-19 is correlated positively with mental health problems [18]. It is likely that, on the one hand, it is necessary to provide people with information in such a way as not to cause excessive fear and panic, which paralyse the mind, and, on the other hand, it is necessary to keep in mind that this information should shape people's responsible behaviour and their own sense of control during the COVID-19 pandemic. Fear and anxiety can play a dual role, both helping people in difficult situations and disturbing them. The research team of Qian et al. [6] have shown the presence of such dual effects. The perception of higher risks and dangers of COVID-19 is positively related to safety and precautionary measures, but at the same time leads to an increase in the level of anxiety symptoms among the population [6]. 
In conclusion, greater concern is significantly associated with a higher PTSS caused by the COVID-19 outbreak, and less concern or lack of concern is associated with a significantly lower degree of PTSS.

Both the original study [9] and this one have their limitations. Firstly, an uneven sample structure is observed, e.g., a significant predominance of women over men. Secondly, psychological methods based on self-report have been used, which may not be fully reliable for assessing mental health. Thirdly, the study is of a cross-sectional nature, which does not allow concluding on the direct impact of the COVID-19 outbreak on the mental health of Polish respondents. Nevertheless, the results of the study are priceless in terms of analyzing a wide range of COVID-19 issues. It is worth noting that these results can be referred to the results of the original study conducted in China [9], which will allow to understand the psychological reactions of society to the COVID-19 outbreak in different cultures.

\section{Conclusions}

1. Almost $20 \%$ of Polish respondents are characterised by a severe or extremely severe level of stress, anxiety, or depressive symptoms. Every seventh respondent reported an extremely severe level of depressive symptoms. Almost every second respondent from Poland is characterized by a severe PTSS caused by the COVID-19 outbreak.

2. Women, families with a household of at least two persons, persons with parental status, unemployed individuals, and persons with poor health and chronic diseases during a pandemic experience more psycho-emotional problems.

3. The occurrence of most physical symptoms directly related to COVID-19 and quarantine is associated with a higher PTSS related to the COVID-19 outbreak.

4. The need for additional information on COVID-19, the application of preventive measures, and increased concerns are significantly associated with increased PTSS related to the COVID-19 outbreak. 5. To develop psychological support programmes, it is necessary to conduct research on the psychological meaning of mental symptoms, in particular depressive and anxiety symptoms during a pandemic, and to highlight the content of mental health problems in different social groups, especially in the risk groups identified in this study. 



\section{References}

1. WHO. Mental health and COVID-19. http://www.euro.who.int/en/health-topics/health-emergencies/ coronavirus-covid-19/technical-guidance/mental-health-and-covid-19. Published 2020. Accessed May $18,2020$.

2. Brooks SK, Webster RK, Smith LE, et al. The psychological impact of quarantine and how to reduce it: rapid review of the evidence. The Lancet. 2020;395(10227):912-920. doi:10.1016/S01406736(20)30460-8

3. UNICEF. Social stigma associated with the coronavirus disease (COVID-19). https://www.unicef.org/documents/social-stigma-associated-coronavirus-disease-covid-19. Published February 24, 2020. Accessed May 18, 2020.

4. Huang Y, Zhao N. Generalized anxiety disorder, depressive symptoms and sleep quality during COVID-19 outbreak in China: a web-based cross-sectional survey. Psychiatry Research. 2020;288:112954. doi:10.1016/j.psychres.2020.112954

5. Sun L, Sun Z, Wu L, et al. Prevalence and Risk Factors of Acute Posttraumatic Stress Symptoms during the COVID-19 Outbreak in Wuhan, China. MedRxiv [published online March 10, 2020]. doi:10.1101/2020.03.06.20032425

6. Qian M, Wu Q, Wu P, et al. Psychological responses, behavioral changes and public perceptions during the early phase of the COVID-19 outbreak in China: a population based cross-sectional survey. MedRxiv [published online February 20, 2020]. doi:10.1101/2020.02.18.20024448

7. Wang Y, Di Y, Ye J, et al. Study on the public psychological states and its related factors during the outbreak of coronavirus disease 2019 (COVID-19) in some regions of China. Psychology, Health \& Medicine [published March 30, 2020]. doi:10.1080/13548506.2020.1746817

8. Lee SA. Coronavirus Anxiety Scale: A brief mental health screener for COVID-19 related anxiety. Death Studies. 2020;44(7):393-401. doi:10.1080/07481187.2020.1748481

9. Wang C, Pan R, Wan X, et al. Immediate Psychological Responses and Associated Factors during the Initial Stage of the 2019 Coronavirus Disease (COVID-19) Epidemic among the General Population in China. International Journal of Environmental Research and Public Health. 2020;17(5):1729. doi:10.3390/ijerph17051729

10. Juczyński Z, Ogińska-Bulik N. Pomiar zaburzeń po stresie traumatycznym - polska wersja Zrewidowanej Skali Wpływu Zdarzeń. [Measurement of post-traumatic stress disorder - Polish version of Impact Event Scale-Revised]. Psychiatria. 2009;6(1):15-25.

11. Lovibond SH, Lovibond PF. Manual for the Depression Anxiety Stress Scales (2nd ed.). Sydney: Psychology Foundation of Australia; 1995. 
12. Wilder-Smith A, Chiew CJ, Lee VJ. Can we contain the COVID-19 outbreak with the same measures as for SARS? The Lancet Infectious Diseases. 2020;20(5):102-107. doi:10.1016/s14733099(20)30129-8

13. Xu J, Zheng Y, Wang M, et al. Predictors of symptoms of posttraumatic stress in Chinese university students during the 2009 H1N1 influenza pandemic. Medical Science Monitor. 2011;17(7):60-64. doi:10.12659/msm.881836

14. Qiu J, Shen B, Zhao M, et al. A nationwide survey of psychological distress among Chinese people in the COVID-19 epidemic: implications and policy recommendations. General Psychiatry. 2020;33(2):e100213. doi:10.1136/gpsych-2020-100213

15. Ahmed MZ, Ahmed O, Aibao Z, et al. Epidemic of COVID-19 in China and associated Psychological Problems. Asian Journal of Psychiatry. 2020;51:102092. doi:10.1016/j.ajp.2020.102092 16. Li JB, Yang A, Dou K, et al. Chinese public's knowledge, perceived severity, and perceived controllability of the COVID-19 and their associations with emotional and behavioural reactions, social participation, and precautionary behaviour: A national survey. Research Square [published online March 10, 2020]. doi:10.21203/rs.3.rs-16572/v1

17. Carvalho LF, Pianowski G, Gonçalves AP. Personality differences and COVID-19: are extroversion and conscientiousness personality traits associated with engagement with containment measures? Trends in Psychiatry and Psychotherapy [published online April 09, 2020]. doi:10.1590/2237-60892020-0029

18. Li JB, Yang A, Dou K, et al. Self-control moderates the association between perceived severity of the coronavirus disease 2019 (COVID-19) and mental health problems among the Chinese public. PsyArXiv [published online March 11, 2020]. doi:10.31234/osf.io/2xadq 
Table 1. Association between demographic variables and the posttraumatic stress symptoms related to the COVID-19 outbreak as well as adverse mental health status during the pandemic $(\mathrm{N}=926)$.

\begin{tabular}{|c|c|c|c|c|c|c|c|c|c|}
\hline \multirow[b]{2}{*}{ Variables } & \multirow[b]{2}{*}{ N (\%) } & \multicolumn{2}{|c|}{ PTSS $^{a}$} & \multicolumn{2}{|c|}{ Stress ${ }^{b}$} & \multicolumn{2}{|c|}{ Anxiety ${ }^{b}$} & \multicolumn{2}{|c|}{ Depression ${ }^{\mathrm{b}}$} \\
\hline & & $R^{2}\left(A R^{2}\right)$ & $\beta(95 \% \mathrm{Cl})$ & $R^{2}\left(A R^{2}\right)$ & $\beta(95 \% \mathrm{Cl})$ & $R^{2}\left(A R^{2}\right)$ & $\beta(95 \% \mathrm{Cl})$ & $R^{2}\left(A R^{2}\right)$ & $\beta(95 \% \mathrm{Cl})$ \\
\hline \multicolumn{10}{|l|}{ Gender } \\
\hline Male & $\begin{array}{c}199 \\
(21.49)\end{array}$ & $\begin{array}{c}0.11 \\
(0.11)\end{array}$ & $\begin{array}{c}-0.34 * * *(- \\
0.40 \text { to }-0.27)\end{array}$ & $\begin{array}{c}0.007 \\
(0.006)\end{array}$ & $\begin{array}{c}-0.09 * *(- \\
0.15 \text { - to - } \\
0.02)\end{array}$ & $\begin{array}{c}0.004 \\
(0.003)\end{array}$ & $\begin{array}{l}-0.06(-0.12 \\
\text { to } 0.01)\end{array}$ & $\begin{array}{c}0.005 \\
(0.004)\end{array}$ & $\begin{array}{c}-0.07 *(-0.13 \\
\text { to }-0.01)\end{array}$ \\
\hline Female & $\begin{array}{c}727 \\
(78.51)\end{array}$ & & Ref. & & Ref. & & Ref. & & Ref. \\
\hline \multicolumn{10}{|l|}{ Age (years) } \\
\hline $18-20$ & $\begin{array}{c}89 \\
(9.29 \%)\end{array}$ & & $\begin{array}{c}-0.22 *(-0.39 \\
\text { to }-0.05)\end{array}$ & & $\begin{array}{l}-0.02(-0.20 \\
\text { to } 0.15)\end{array}$ & & $\begin{array}{l}-0.02(-0.20 \\
\text { to } 0.15)\end{array}$ & & $\begin{array}{l}-0.02(-0.19 \\
\text { to } 0.16)\end{array}$ \\
\hline $20-30$ & $\begin{array}{c}313 \\
(33.80)\end{array}$ & & $\begin{array}{c}-0.09(-0.20 \\
\text { to } 0.01)\end{array}$ & & $\begin{array}{c}0.01(-0.09- \\
0.12)\end{array}$ & & $\begin{array}{c}0.04(-0.07 \mathrm{do} \\
0.14)\end{array}$ & & $\begin{array}{c}0.02 \text { (0.09 to } \\
0.12)\end{array}$ \\
\hline $30-40$ & $\begin{array}{c}248 \\
(26.78)\end{array}$ & $\begin{array}{c}0.004 \\
(0.003)\end{array}$ & $\begin{array}{l}-0.09(-0.20 \\
\text { to } 0.03)\end{array}$ & $\begin{array}{c}<0.001 \\
(<0.001)\end{array}$ & $\begin{array}{l}-0.06(-0.17 \\
\text { to } 0.06)\end{array}$ & $\begin{array}{c}0.002 \\
(0.001)\end{array}$ & $\begin{array}{l}-0.05(-0.17 \\
\text { to } 0.06)\end{array}$ & $\begin{array}{l}<0.001 \\
(<0.001)\end{array}$ & $\begin{array}{l}-0.06(-0.17 \\
\text { to } 0.06)\end{array}$ \\
\hline $40-50$ & $\begin{array}{c}154 \\
(16.63)\end{array}$ & & $\begin{array}{c}-0.01(-0.15 \\
\text { to } 0.13)\end{array}$ & & $\begin{array}{c}-0.08(-0.22 \\
\text { to } 0.06)\end{array}$ & & $\begin{array}{c}-0.09(-0.23 \\
\text { to } 0.05)\end{array}$ & & $\begin{array}{c}-0.05(-0.19- \\
0.09)\end{array}$ \\
\hline $50-60$ & $\begin{array}{c}83 \\
(8.96)\end{array}$ & & $\begin{array}{c}-0.07(-0.25 \\
\text { to } 0.10)\end{array}$ & & $\begin{array}{c}0.06(-0.11 \text { to } \\
0.24)\end{array}$ & & $\begin{array}{c}0.04(-0.14 \text { to } \\
0.22)\end{array}$ & & $\begin{array}{c}0.03(-0.15 \text { to } \\
0.21)\end{array}$ \\
\hline$>60$ & $\begin{array}{c}42 \\
(4.54)\end{array}$ & & Ref. & & Ref. & & Ref. & & Ref. \\
\hline \multicolumn{10}{|l|}{$\begin{array}{l}\text { Parental } \\
\text { status }\end{array}$} \\
\hline $\begin{array}{l}\text { Has a child } 16 \\
\text { years or } \\
\text { under }\end{array}$ & $\begin{array}{c}349 \\
(37.69)\end{array}$ & & $\begin{array}{c}0.16^{* * *} \\
(0.09 \text { to } 0.23)\end{array}$ & & $\begin{array}{l}-0.05(-0.12 \\
\text { to } 0.02)\end{array}$ & & $\begin{array}{l}-0.05(-0.12 \\
\text { to } 0.02)\end{array}$ & & $\begin{array}{l}-0.06(-0.13 \\
\text { to } 0.02)\end{array}$ \\
\hline $\begin{array}{l}\text { Has a child } \\
\text { older than } 16 \\
\text { years }\end{array}$ & $\begin{array}{c}138 \\
(14.90)\end{array}$ & $\begin{array}{c}0.02 \\
(0.02)\end{array}$ & $\begin{array}{c}0.15^{* * *} \\
(0.07 \text { to } 0.24)\end{array}$ & $\begin{array}{c}<0.001(- \\
0.001)\end{array}$ & $\begin{array}{c}0.01(-0.07 \text { to } \\
0.09)\end{array}$ & $\begin{array}{c}0.002 \\
(<0.001)\end{array}$ & $\begin{array}{l}-0.04(-0.12 \\
\text { to } 0.05)\end{array}$ & $\begin{array}{l}<0.001(- \\
0.001)\end{array}$ & $\begin{array}{c}0.01(-0.08 \text { to } \\
0.09)\end{array}$ \\
\hline $\begin{array}{l}\text { Children } \\
\text { under and } \\
\text { over } 16 \text { years } \\
\text { of age }\end{array}$ & $\begin{array}{c}30 \\
(3.24)\end{array}$ & & $\begin{array}{c}0.09(-0.01 \text { to } \\
0.18)\end{array}$ & & $\begin{array}{c}0.01(-0.08 \text { to } \\
0.11)\end{array}$ & & $\begin{array}{l}-0.03(-0.12 \\
\text { to } 0.06)\end{array}$ & & $\begin{array}{c}0.01(-0.09 \text { to } \\
0.10)\end{array}$ \\
\hline No children & $\begin{array}{c}409 \\
(44.17) \\
\end{array}$ & & Ref. & & Ref. & & Ref. & & Ref. \\
\hline \multicolumn{10}{|l|}{$\begin{array}{l}\text { Marital } \\
\text { status }\end{array}$} \\
\hline Single & 176 (19) & & $\begin{array}{c}-0.19^{* *}(- \\
0.33 \text { to }-0.05)\end{array}$ & & $\begin{array}{c}0.11(-0.03 \text { to } \\
0.25)\end{array}$ & & $\begin{array}{l}0.15 *(0.01 \\
\text { to } 0.29)\end{array}$ & & $\begin{array}{l}0.15 *(0.01 \\
\text { to } 0.29)\end{array}$ \\
\hline $\begin{array}{l}\text { Informal } \\
\text { relationship }\end{array}$ & $\begin{array}{c}279 \\
(30.13)\end{array}$ & $\begin{array}{c}0.005 \\
(0.004)\end{array}$ & $\begin{array}{c}-0.09(-0.20 \\
\text { to } 0.02)\end{array}$ & $\begin{array}{c}<0.001(- \\
0.001)\end{array}$ & $\begin{array}{c}0.11(-0.01 \text { to } \\
0.22)\end{array}$ & $\begin{array}{c}<0.001(- \\
0.001)\end{array}$ & $\begin{array}{l}0.13^{*}(0.02 \\
\text { to } 0.25)\end{array}$ & $\begin{array}{l}<0.001 \\
(<0.001)\end{array}$ & $\begin{array}{l}0.13^{*}(0.02 \\
\text { to } 0.24)\end{array}$ \\
\hline Married & $\begin{array}{c}399 \\
(43.09)\end{array}$ & & $\begin{array}{l}-0.06(-0.15 \\
\text { to } 0.04)\end{array}$ & & $\begin{array}{c}0.07(-0.03 \text { to } \\
0.17)\end{array}$ & & $\begin{array}{l}0.10(<-0.001 \\
\text { to } 0.19)\end{array}$ & & $\begin{array}{c}0.10^{*} \\
(<0.001 \text { to } \\
0.19)\end{array}$ \\
\hline Divorced & $\begin{array}{c}52 \\
(6.62)\end{array}$ & & Redundancy $^{c}$ & & Redundancy $^{c}$ & & Redundancy $^{c}$ & & Redundancy $^{\mathrm{C}}$ \\
\hline Widowed & $\begin{array}{c}20 \\
(2.16) \\
\end{array}$ & & Ref. & & Ref. & & Ref. & & Ref. \\
\hline \multicolumn{10}{|l|}{$\begin{array}{l}\text { Household } \\
\text { size }\end{array}$} \\
\hline $\begin{array}{l}\text { Six people or } \\
\text { more }\end{array}$ & $\begin{array}{c}55 \\
(5.94)\end{array}$ & & $\begin{array}{l}0.26^{* *}(0.09 \\
\text { to } 0.43)\end{array}$ & & $\begin{array}{c}0.10(-0.07 \text { to } \\
0.27)\end{array}$ & & $\begin{array}{c}0.10(-0.07 \text { to } \\
0.27\end{array}$ & & $\begin{array}{c}0.11(-0.06 \text { to } \\
0.29)\end{array}$ \\
\hline $\begin{array}{l}\text { Three to five } \\
\text { people }\end{array}$ & $\begin{array}{c}553 \\
(59.72)\end{array}$ & $\begin{array}{c}0.001 \\
(<0.001)\end{array}$ & $\begin{array}{l}0.13^{* *}(0.05 \\
\quad \text { to } 0.21)\end{array}$ & $\begin{array}{c}0.001 \\
(<0.001)\end{array}$ & $\begin{array}{c}0.04(-0.04 \text { to } \\
0.11)\end{array}$ & $\begin{array}{c}0.004 \\
(0.002)\end{array}$ & $\begin{array}{c}0.06(-0.02 \text { to } \\
0.14)\end{array}$ & $\begin{array}{c}0.002 \\
(0.001)\end{array}$ & $\begin{array}{c}0.04(-0.03 \text { to } \\
0.12)\end{array}$ \\
\hline Two people & $\begin{array}{c}241 \\
(26.03)\end{array}$ & & $\begin{array}{l}0.12 *(0.01 \\
\text { to } 0.23)\end{array}$ & & $\begin{array}{c}0.07(-0.04 \text { to } \\
0.18)\end{array}$ & & $\begin{array}{c}0.10(-0.01 \text { to } \\
0.21)\end{array}$ & & $\begin{array}{c}0.09(-0.02 \text { to } \\
0.20)\end{array}$ \\
\hline
\end{tabular}




\begin{tabular}{|c|c|c|c|c|c|c|c|c|c|}
\hline One person & $\begin{array}{c}77 \\
(8.32)\end{array}$ & & Ref. & & Ref. & & Ref. & & Ref. \\
\hline \multicolumn{10}{|l|}{$\begin{array}{l}\text { Employment } \\
\text { status }\end{array}$} \\
\hline Unemployed & $\begin{array}{c}196 \\
(21.17)\end{array}$ & & $\begin{array}{c}0.04(-0.04 \text { to } \\
0.11)\end{array}$ & & $\begin{array}{c}0.12^{* * *} \\
(0.06 \text { to } 0.20)\end{array}$ & & $\begin{array}{c}0.17^{* * *} \\
(0.10 \text { to } 0.24)\end{array}$ & & $\begin{array}{c}0.11 * *(0.04 \\
\text { to } 0.19)\end{array}$ \\
\hline Retired & $\begin{array}{c}49 \\
(5.29)\end{array}$ & & $\begin{array}{c}0.04(-0.04 \text { to } \\
0.12)\end{array}$ & & $\begin{array}{c}0.04(-0.05 \text { to } \\
0.12)\end{array}$ & & $\begin{array}{c}0.03(-0.05 \text { to } \\
0.12)\end{array}$ & & $\begin{array}{c}0.04(-0.04 \text { to } \\
0.12)\end{array}$ \\
\hline Student & $9(0.97)$ & $\begin{array}{c}<0.001 \\
(<0.001)\end{array}$ & $\begin{array}{c}-0.09 *(-0.18 \\
\text { to }-0.01)\end{array}$ & $\begin{array}{c}0.001 \\
(<0.001)\end{array}$ & $\begin{array}{c}-0.01(-0.09 \\
\text { to } 0.08)\end{array}$ & $\begin{array}{c}0.002 \\
(<0.001)\end{array}$ & $\begin{array}{c}0.01(-0.08 \text { to } \\
0.09)\end{array}$ & $\begin{array}{c}0.002 \\
(<0.001)\end{array}$ & $\begin{array}{c}0.03(-0.06 \text { to } \\
0.12)\end{array}$ \\
\hline $\begin{array}{l}\text { Student and } \\
\text { employed }\end{array}$ & $\begin{array}{c}106 \\
(11.45)\end{array}$ & & $\begin{array}{c}-0.04(-0.13 \\
\text { to } 0.02)\end{array}$ & & $\begin{array}{c}0.04(-0.04 \text { to } \\
0.20)\end{array}$ & & $\begin{array}{c}0.05(-0.02 \text { to } \\
0.13)\end{array}$ & & $\begin{array}{c}0.04(-0.03 \text { to } \\
0.12)\end{array}$ \\
\hline $\begin{array}{c}\text { Other (e.g. } \\
\text { maternity } \\
\text { leave) }\end{array}$ & $\begin{array}{c}59 \\
(6.37)\end{array}$ & & $\begin{array}{c}0.01(-0.07 \text { to } \\
0.09)\end{array}$ & & $\begin{array}{c}0.04(-0.05 \text { to } \\
0.12)\end{array}$ & & $\begin{array}{c}0.03(-0.05 \text { to } \\
0.11)\end{array}$ & & $\begin{array}{c}0.04(-0.04 \text { to } \\
0.12)\end{array}$ \\
\hline Employed & $\begin{array}{c}507 \\
(54.75)\end{array}$ & & Ref. & & Ref. & & Ref. & & Ref. \\
\hline \multicolumn{10}{|l|}{$\begin{array}{l}\text { Educational } \\
\text { attainment }\end{array}$} \\
\hline $\begin{array}{c}\text { Primary } \\
\text { school }\end{array}$ & $\begin{array}{c}27 \\
(2.92)\end{array}$ & & $\begin{array}{c}0.03(-0.06 \text { to } \\
0.12)\end{array}$ & & $\begin{array}{c}0.04(-0.06 \text { to } \\
0.13)\end{array}$ & & $\begin{array}{c}0.05(-0.05 \text { to } \\
0.14)\end{array}$ & & $\begin{array}{c}0.01(-0.08 \text { to } \\
0.11)\end{array}$ \\
\hline Vocational & $\begin{array}{c}61 \\
(6.59)\end{array}$ & $\begin{array}{c}<0.001 \\
(<0.001)\end{array}$ & $\begin{array}{c}0.07(-0.02 \text { to } \\
0.16)\end{array}$ & $\begin{array}{c}0.001 \\
(<0.001)\end{array}$ & $\begin{array}{c}-0.02(-0.11 \\
\text { to } 0.07)\end{array}$ & $\begin{array}{c}0.002 \\
(0.001)\end{array}$ & $\begin{array}{c}-0.04(-0.13 \\
\text { to } 0.05)\end{array}$ & $\begin{array}{c}0.001 \\
(<0.001)\end{array}$ & $\begin{array}{c}-0.03(-0.13 \\
\text { to } 0.06)\end{array}$ \\
\hline $\begin{array}{l}\text { Secondary } \\
\text { education }\end{array}$ & $\begin{array}{c}430 \\
(46.44)\end{array}$ & & $\begin{array}{c}-0.02(-0.09 \\
\text { to } 0.04)\end{array}$ & & $\begin{array}{c}0.04(-0.02 \text { to } \\
0.11)\end{array}$ & & $\begin{array}{c}0.06(-0.01 \text { to } \\
0.13)\end{array}$ & & $\begin{array}{c}0.05(-0.02 \text { to } \\
0.12)\end{array}$ \\
\hline $\begin{array}{c}\text { Higher } \\
\text { education }\end{array}$ & $\begin{array}{c}408 \\
(44.06)\end{array}$ & & Ref. & & Ref. & & Ref. & & Ref. \\
\hline
\end{tabular}

$* p<0.05 ; * * p<0.01 ; p<0.001$.

$\mathrm{AR}^{2}$, Adjusted R-Squared; $\mathrm{Cl}$, confidence interval; N, number; Ref., reference.

a Posttraumatic stress symptoms were measured using the Impact of Event Scale-Revised (IES-R).

${ }^{\mathrm{b}}$ Depression, Anxiety and Stress were measured using the Depression Anxiety Stress Scale (DASS-21).

${ }^{\mathrm{c}}$ The predictors did not exceed the tolerance value. 
Table 2. Association between physical health status in the past 14 days and the posttraumatic stress symptoms related to the COVID-19 outbreak as well as adverse mental health status during the pandemic $(\mathrm{N}=926)$.

\begin{tabular}{|c|c|c|c|c|c|c|c|c|c|}
\hline \multirow[b]{2}{*}{ Variables } & \multirow[b]{2}{*}{$\mathrm{N}(\%)$} & \multicolumn{2}{|c|}{ PTSS $^{\text {a }}$} & \multicolumn{2}{|c|}{ Stress $^{b}$} & \multicolumn{2}{|c|}{ Anxiety $^{b}$} & \multicolumn{2}{|c|}{ Depression $^{\mathrm{b}}$} \\
\hline & & $R^{2}\left(A R^{2}\right)$ & $\beta$ 95\% Cl) & $R^{2}\left(A R^{2}\right)$ & $\beta(95 \% \mathrm{Cl})$ & $R^{2}\left(A R^{2}\right)$ & $\beta(95 \% \mathrm{Cl})$ & $R^{2}\left(A R^{2}\right)$ & $\beta(95 \% \mathrm{Cl})$ \\
\hline \multicolumn{10}{|c|}{ Persistent fever ( $>38^{\circ} \mathrm{C}$ for at least 1 day) } \\
\hline Yes & $20(2.16)$ & $\begin{array}{c}0.001 \\
(<0.001)\end{array}$ & $\begin{array}{c}0.03(-0.04 \\
\text { to } 0.09)\end{array}$ & $\begin{array}{l}<0.001 \\
(0.001)\end{array}$ & $\begin{array}{c}-0.01(-0.08 \\
\text { to } 0.05)\end{array}$ & $\begin{array}{c}0.001 \\
(<0.001)\end{array}$ & $\begin{array}{c}-0.03(- \\
0.09 \text { to } \\
0.04)\end{array}$ & $\begin{array}{l}<0.001 \\
(0.001)\end{array}$ & $\begin{array}{l}\text { \#POLE! } \\
(-0.08 \text { to } \\
0.05)\end{array}$ \\
\hline No & $906(97.84)$ & & Ref. & & Ref. & & Ref. & & Ref. \\
\hline \multicolumn{10}{|l|}{ Chills } \\
\hline Yes & $75(8.10)$ & $\begin{array}{c}0.006 \\
(0.005)\end{array}$ & $\begin{array}{c}0.08 *(0.01 \\
\text { to } 0.14)\end{array}$ & $\begin{array}{c}0.001 \\
(0.001)\end{array}$ & $\begin{array}{c}0.03(-0.03 \\
\text { to } 0.10)\end{array}$ & $\begin{array}{c}<0.001(- \\
0.001)\end{array}$ & $\begin{array}{c}0.01(-0.05 \\
\text { to } 0.08)\end{array}$ & $\begin{array}{c}0.002 \\
(0.001)\end{array}$ & $\begin{array}{c}0.04(-0.02 \\
\text { to } 0.10)\end{array}$ \\
\hline No & $851(91.90)$ & & Ref. & & Ref. & & Ref. & & Ref. \\
\hline \multicolumn{10}{|l|}{ Headache } \\
\hline Yes & $475(51.30)$ & $\begin{array}{c}0.041 \\
(0.040)\end{array}$ & $\begin{array}{c}0.20^{* * *} \\
(0.14 \text { to } \\
0.27)\end{array}$ & $\begin{array}{c}0.001 \\
(<0.001)\end{array}$ & $\begin{array}{c}0.03(-0.03 \\
\text { to } 0.10)\end{array}$ & $\begin{array}{c}0.001(- \\
0.001)\end{array}$ & $\begin{array}{c}0.02(-0.04 \\
\text { to } 0.09)\end{array}$ & $\begin{array}{c}0.002 \\
(0.001)\end{array}$ & $\begin{array}{c}0.05(-0.02 \\
\text { to } 0.11)\end{array}$ \\
\hline No & $451(48.70)$ & & Ref. & & Ref. & & Ref. & & Ref. \\
\hline \multicolumn{10}{|l|}{ Myalgia } \\
\hline Yes & $161(17.39)$ & $\begin{array}{c}0.017 \\
(0.016)\end{array}$ & $\begin{array}{c}0.13^{* * *} \\
(0.07 \text { to } \\
0.19)\end{array}$ & $\begin{array}{c}0.001 \\
(<0.001)\end{array}$ & $\begin{array}{c}0.03(-0.04 \\
\text { to } 0.09)\end{array}$ & $\begin{array}{c}0.001 \\
(0.001)\end{array}$ & $\begin{array}{c}0.02(-0.04 \\
\text { to } 0.09)\end{array}$ & $\begin{array}{c}<0.001(- \\
0.001)\end{array}$ & $\begin{array}{c}0.01(-0.06 \\
\text { to } 0.07)\end{array}$ \\
\hline No & $765(82.61)$ & & Ref. & & Ref. & & Ref. & & Ref. \\
\hline \multicolumn{10}{|l|}{ Cough } \\
\hline Yes & $289(31.21)$ & $\begin{array}{c}0.012 \\
(0.011)\end{array}$ & $\begin{array}{c}0.11^{* * *} \\
(0.05 \text { to } \\
0.17)\end{array}$ & $\begin{array}{c}0.002 \\
(0.001)\end{array}$ & $\begin{array}{c}-0.05(-0.11 \\
\text { to } 0.02)\end{array}$ & $\begin{array}{c}0.002 \\
(0.001)\end{array}$ & $\begin{array}{c}-0.05(- \\
0.11 \text { to } \\
0.02)\end{array}$ & $\begin{array}{c}0.004 \\
(0.002)\end{array}$ & $\begin{array}{c}-0.06(-0.13 \\
\text { to } 0.003)\end{array}$ \\
\hline No & $637(68.79)$ & & Ref. & & Ref. & & Ref. & & Ref. \\
\hline \multicolumn{10}{|c|}{ Breathing difficulty } \\
\hline Yes & $80(8.64)$ & $\begin{array}{c}0.030 \\
(0.029)\end{array}$ & $\begin{array}{c}0.17 * * * \\
(0.11 \text { to } \\
0.24)\end{array}$ & $\begin{array}{l}<0.001 \\
(0.001)\end{array}$ & $\begin{array}{c}-0.01(-0.07 \\
\text { to } 0.05)\end{array}$ & $\begin{array}{c}<0.001(- \\
0.001)\end{array}$ & $\begin{array}{c}-0.01(- \\
0.07 \text { to } \\
0.06)\end{array}$ & $\begin{array}{c}0.001(- \\
0.001)\end{array}$ & $\begin{array}{c}-0.01(-0.08 \\
\text { to } 0.05)\end{array}$ \\
\hline No & $846(91.36)$ & & Ref. & & Ref. & & Ref. & & Ref. \\
\hline \multicolumn{10}{|l|}{ Dizziness } \\
\hline Yes & $130(14.04)$ & $\begin{array}{c}0.022 \\
(0.021)\end{array}$ & $\begin{array}{c}0.15^{* * *} \\
(0.08 \text { to } \\
0.21)\end{array}$ & $\begin{array}{c}0.002 \\
(0.001)\end{array}$ & $\begin{array}{c}0.04(-0.02 \\
\text { to } 0.11)\end{array}$ & $\begin{array}{c}<0.001(- \\
0.001)\end{array}$ & $\begin{array}{c}0.02(-0.04 \\
\text { to } 0.09)\end{array}$ & $\begin{array}{c}0.003 \\
(0.001)\end{array}$ & $\begin{array}{c}0.05(-0.01 \\
\text { to } 0.12)\end{array}$ \\
\hline No & $796(85.96)$ & & Ref. & & Ref. & & Ref. & & Ref. \\
\hline \multicolumn{10}{|l|}{ Coryza } \\
\hline Yes & $342(36.93)$ & $\begin{array}{c}0.006 \\
(0.005)\end{array}$ & $\begin{array}{l}0.08^{* *}(0.01 \\
\text { to } 0.14)\end{array}$ & $\begin{array}{c}<0.001(- \\
0.001)\end{array}$ & $\begin{array}{c}-0.02(-0.09 \\
\text { to } 0.04)\end{array}$ & $\begin{array}{c}<0.001(- \\
0.001)\end{array}$ & $\begin{array}{c}0.01(-0.05 \\
\text { to } 0.08)\end{array}$ & $\begin{array}{c}0.001 \\
(<0.001)\end{array}$ & $\begin{array}{c}-0.02(-0.09 \\
\text { to } 0.04)\end{array}$ \\
\hline No & $584(93.07)$ & & Ref. & & Ref. & & Ref. & & Ref. \\
\hline \multicolumn{10}{|l|}{ Sore throat } \\
\hline Yes & $296(31.97)$ & $\begin{array}{c}0.019 \\
(0.018)\end{array}$ & $\begin{array}{c}0.14^{* * *} \\
(0.08 \text { to } \\
0.20)\end{array}$ & $\begin{array}{c}0.001 \\
(<0.001)\end{array}$ & $\begin{array}{c}-0.03(-0.10 \\
\text { to } 0.03)\end{array}$ & $\begin{array}{c}<0.001(- \\
0.001)\end{array}$ & $\begin{array}{c}-0.01(- \\
0.07 \text { to } \\
0.06)\end{array}$ & $\begin{array}{c}<0.001(- \\
0.001)\end{array}$ & $\begin{array}{c}<0.001 \text { (- } \\
0.06 \text { to } \\
0.06)\end{array}$ \\
\hline No & $630(68.03)$ & & Ref. & & Ref. & & Ref. & & Ref. \\
\hline \multicolumn{10}{|c|}{ Persistent fever and cough or difficulty breathing } \\
\hline Yes & $17(1.84)$ & $\begin{array}{c}0.003 \\
(0.002)\end{array}$ & $\begin{array}{c}0.05(-0.001 \\
\text { to } 0.12)\end{array}$ & $\begin{array}{c}<0.001 \text { (- } \\
0.001)\end{array}$ & $\begin{array}{l}<0.001 \text { (- } \\
0.06 \text { to }\end{array}$ & $\begin{array}{c}<0.001(- \\
0.001)\end{array}$ & $\begin{array}{c}-0.01(-0.08 \\
\text { to } 0.05)\end{array}$ & $\begin{array}{c}<0.001(- \\
0.001)\end{array}$ & $\begin{array}{c}0.01(-0.05 \\
\text { to } 0.008)\end{array}$ \\
\hline
\end{tabular}




\begin{tabular}{|c|c|c|c|c|c|c|c|c|c|}
\hline \multirow{2}{*}{ No } & \multicolumn{9}{|c|}{$0.06)$} \\
\hline & \multicolumn{2}{|l|}{$909(98.16)$} & \multicolumn{2}{|l|}{ Ref. } & \multicolumn{2}{|l|}{ Ref. } & \multicolumn{2}{|l|}{ Ref. } & \multirow[t]{2}{*}{ Ref. } \\
\hline \multicolumn{9}{|c|}{ Consultation with doctor in the clinic in the past 14 days } & \\
\hline Yes & $84(9.07)$ & $\begin{array}{c}0.009 \\
(0.008)\end{array}$ & $\begin{array}{l}0.10^{* *}(0.03 \\
\text { to } 0.16)\end{array}$ & $\begin{array}{l}<0.001 \\
(0.001)\end{array}$ & $\begin{array}{l}0.02(-0.05 \\
\text { to } 0.08)\end{array}$ & $\begin{array}{c}<0.001(- \\
0.001)\end{array}$ & $\begin{array}{c}-0.01(- \\
0.08 \text { to } \\
0.05)\end{array}$ & $<0.001$ & $\begin{array}{c}-0.01(-0.08 \\
\text { to } 0.05)\end{array}$ \\
\hline No & $842(90.93)$ & & Ref. & & Ref. & & Ref. & & Ref. \\
\hline \multicolumn{10}{|c|}{ Recent hospitalization in the past 14 days } \\
\hline Yes & $4(0.43)$ & $\begin{array}{l}0.001(- \\
0.001)\end{array}$ & $\begin{array}{c}0.01(-0.05 \\
\text { to } 0.08)\end{array}$ & $\begin{array}{c}0.001 \\
(<0.001)\end{array}$ & $\begin{array}{c}0.03(-0.04 \\
\text { to } 0.09)\end{array}$ & $\begin{array}{c}<0.001 \text { (- } \\
0.001)\end{array}$ & $\begin{array}{l}0.01(-0.06 \\
\text { to } 0.07)\end{array}$ & $\begin{array}{c}<0.001(- \\
0.001)\end{array}$ & $\begin{array}{c}0.01(-0.05 \\
\text { to } 0.07)\end{array}$ \\
\hline No & $922(99.97)$ & & Ref. & & Ref. & & Ref. & & Ref. \\
\hline \multicolumn{10}{|c|}{ Recent testing for COVID-19 in the past 14 days } \\
\hline Yes & $8(0.86)$ & $\begin{array}{c}0.002 \\
(0.001)\end{array}$ & $\begin{array}{c}0.04(-0.02 \\
\text { to } 0.11)\end{array}$ & $\begin{array}{c}0.001 \\
(<0.001)\end{array}$ & $\begin{array}{c}0.03(-0.03 \\
\text { to } 0.10)\end{array}$ & $\begin{array}{c}0.001 \\
(<0.001)\end{array}$ & $\begin{array}{c}0.03(-0.04 \\
\text { to } 0.09)\end{array}$ & $\begin{array}{c}<0.001(- \\
0.001)\end{array}$ & $\begin{array}{c}<0.001 \text { (- } \\
0.06 \text { to } \\
0.07)\end{array}$ \\
\hline No & 918 (99.16) & & Ref. & & Ref. & & Ref. & & Ref. \\
\hline \multicolumn{10}{|c|}{ Recent quarantine in the past 14 days } \\
\hline Yes & $53(5.72)$ & $\begin{array}{c}0.007 \\
(0.006)\end{array}$ & $\begin{array}{c}0.08 *(0.02 \\
\text { to } 0.15)\end{array}$ & $\begin{array}{c}0.002 \\
(0.001)\end{array}$ & $\begin{array}{c}0.05(-0.02 \\
\text { to } 0.11)\end{array}$ & $\begin{array}{c}0.001 \\
(<0.001)\end{array}$ & $\begin{array}{c}0.03(-0.03 \\
\text { to } 0.09)\end{array}$ & $\begin{array}{c}0.001 \\
(<0.001)\end{array}$ & $\begin{array}{c}0.03(-0.03 \\
\text { to } 0.10)\end{array}$ \\
\hline No & $873(94.28)$ & & Ref. & & Ref. & & Ref. & & Ref. \\
\hline \multicolumn{10}{|c|}{ Current self-rating health status } \\
\hline $\begin{array}{c}\text { Poor/Very } \\
\text { poor }\end{array}$ & $48(5.18)$ & & $\begin{array}{l}0.12^{* * *} \\
(0.05 \text { to } \\
0.19)\end{array}$ & & $\begin{array}{c}0.001(- \\
0.06 \text { to } \\
0.08)\end{array}$ & & $\begin{array}{c}0.04(-0.04 \\
\text { to } 0.11)\end{array}$ & & $\begin{array}{c}<0.001 \text { (- } \\
0.07 \text { to } \\
0.07)\end{array}$ \\
\hline Average & $213(23.00)$ & $\begin{array}{c}0.042 \\
(0.041)\end{array}$ & $\begin{array}{l}0.20^{* * *} \\
(0.14 \text { to } \\
0.27)\end{array}$ & $\begin{array}{c}0.001 \\
(<0.001)\end{array}$ & $\begin{array}{c}0.03(-0.10 \\
\text { to } 0.03)\end{array}$ & $\begin{array}{c}0.002 \\
(0.001)\end{array}$ & $\begin{array}{c}-0.05(- \\
0.12 \text { to } \\
0.01)\end{array}$ & $\begin{array}{c}0.001 \\
(<0.001)\end{array}$ & $\begin{array}{c}-0.03(-0.09 \\
\text { to } 0.03)\end{array}$ \\
\hline $\begin{array}{c}\text { Good/Very } \\
\text { good }\end{array}$ & $665(71.81)$ & & Ref. & & Ref. & & Ref. & & Ref. \\
\hline \multicolumn{10}{|c|}{ Medical insurance coverage } \\
\hline Yes & $308(33.26)$ & $\begin{array}{c}0.035 \\
(0.034)\end{array}$ & $\begin{array}{l}0.19 * * * \\
(0.12 \text { to } \\
0.25)\end{array}$ & $\begin{array}{l}<0.001 \\
(0.001)\end{array}$ & $\begin{array}{l}0.02(-0.05 \\
\text { to } 0.08)\end{array}$ & $\begin{array}{l}<0.001 \\
(0.001)\end{array}$ & $\begin{array}{c}-0.02,(- \\
0.08 \text { to } \\
0.04)\end{array}$ & $\begin{array}{c}<0.001(- \\
0.001)\end{array}$ & $\begin{array}{c}-0.02(-0.08 \\
\text { to } 0.05)\end{array}$ \\
\hline No & 618 (66.74) & & Ref. & & Ref. & & Ref. & & Ref. \\
\hline
\end{tabular}

$* p<0.05 ; * * p<0.01 ; p<0.001$.

$\mathrm{AR}^{2}$, Adjusted R-Squared; Cl, confidence interval; N, number; Ref., reference.

a Posttraumatic stress symptoms were measured using the Impact of Event Scale-Revised (IES-R).

${ }^{\mathrm{b}}$ Depression, Anxiety and Stress were measured using the Depression Anxiety Stress Scale (DASS-21). 
Table 3. Association between contact history in the past 14 days and the posttraumatic stress symptoms related to the COVID-19 outbreak as well as adverse mental health status during the pandemic $(\mathrm{N}=$ 926).

\begin{tabular}{|c|c|c|c|c|c|c|c|c|c|}
\hline \multirow[b]{2}{*}{ Variables } & \multirow[b]{2}{*}{$\mathrm{N}(\%)$} & \multicolumn{2}{|c|}{ PTSS $^{\text {a }}$} & \multicolumn{2}{|c|}{ Stress $^{b}$} & \multicolumn{2}{|c|}{ Anxiety ${ }^{b}$} & \multicolumn{2}{|c|}{ Depression $^{b}$} \\
\hline & & $R^{2}\left(A R^{2}\right)$ & $\beta(95 \% \mathrm{Cl})$ & $R^{2}\left(A R^{2}\right)$ & $\beta(95 \% \mathrm{Cl})$ & $R^{2}\left(A R^{2}\right)$ & $\beta(95 \% \mathrm{Cl})$ & $R^{2}\left(A R^{2}\right)$ & $\beta(95 \% \mathrm{Cl})$ \\
\hline \multicolumn{10}{|c|}{ Close contact with an individual with confirmed infection with COVID-19 } \\
\hline Yes & $4(0.43)$ & $\begin{array}{c}0.001 \\
(<0.001)\end{array}$ & $\begin{array}{c}0.03(-0.04 \\
\text { to } 0.09)\end{array}$ & $\begin{array}{c}0.002 \\
(0.001)\end{array}$ & $\begin{array}{c}-0.04(- \\
0.11 \text { to } \\
0.02)\end{array}$ & $\begin{array}{c}<0.001(- \\
0.001)\end{array}$ & $\begin{array}{c}-0.01(-0.08 \\
\text { to } 0.05)\end{array}$ & $\begin{array}{c}0.001 \\
(<0.001)\end{array}$ & $\begin{array}{c}-0.04(-0.10 \\
\text { to } 0.03)\end{array}$ \\
\hline No & $922(99.57)$ & & Ref. & & Ref. & & Ref. & & Ref. \\
\hline \multicolumn{10}{|c|}{ Indirect contact with an individual with confirmed infection with COVID-19 } \\
\hline Yes & $14(1.51)$ & $\begin{array}{c}0.002 \\
(0.001)\end{array}$ & $\begin{array}{c}-0.04(- \\
0.11 \text { to } \\
0.02)\end{array}$ & $\begin{array}{c}0.003 \\
(0.002)\end{array}$ & $\begin{array}{c}-0.05(- \\
0.12 \text { to } \\
0.01)\end{array}$ & $\begin{array}{c}0.004 \\
(0.003)\end{array}$ & $\begin{array}{l}-0.06(-0.13 \\
\text { to }<0.001)\end{array}$ & $\begin{array}{c}0.002 \\
(0.001)\end{array}$ & $\begin{array}{c}-0.05(-0.11 \\
\text { to } 0.02)\end{array}$ \\
\hline No & $912(99.49)$ & & Ref. & & Ref. & & Ref. & & Ref. \\
\hline \multicolumn{10}{|c|}{ Contact with an individual with suspected COVID-19 or infected materials } \\
\hline Yes & $43(4.64$ & $\begin{array}{c}0.002 \\
(0.001)\end{array}$ & $\begin{array}{c}0.05(-0.02 \\
\text { to } 0.11)\end{array}$ & $\begin{array}{c}0.002 \\
(0.001)\end{array}$ & $\begin{array}{c}-0.05(- \\
0.11 \text { to } \\
0.02)\end{array}$ & $\begin{array}{c}0.002 \\
(0.001)\end{array}$ & $\begin{array}{c}-0.04(-0.11 \\
\text { to } 0.02)\end{array}$ & $\begin{array}{c}0.004 \\
(0.004)\end{array}$ & $\begin{array}{c}-0.06 *(- \\
0.13 \text { to }- \\
0.001)\end{array}$ \\
\hline No & $883(95.96)$ & & Ref. & & Ref. & & Ref. & & Ref. \\
\hline
\end{tabular}

$* p<0.05 ; * * p<0.01 ; p<0.001$.

$\mathrm{AR}^{2}$, Adjusted R-Squared; Cl, confidence interval; N, number; Ref., reference.

${ }^{a}$ Posttraumatic stress symptoms were measured using the Impact of Event Scale-Revised (IES-R).

${ }^{\mathrm{b}}$ Depression, Anxiety and Stress were measured using the Depression Anxiety Stress Scale (DASS-21). 
Table 4. Association between knowledge and concerns about coronavirus disease and the posttraumatic stress symptoms related to the COVID-19 outbreak as well as adverse mental health status during the pandemic $(\mathrm{N}=926)$.

\begin{tabular}{|c|c|c|c|c|c|c|c|c|c|}
\hline \multirow[b]{2}{*}{ Variables } & \multirow[b]{2}{*}{$\mathrm{N}(\%)$} & \multicolumn{2}{|c|}{ PTSS $^{\text {a }}$} & \multicolumn{2}{|r|}{ Stress $^{b}$} & \multicolumn{2}{|c|}{ Anxiety $^{b}$} & \multicolumn{2}{|c|}{ Depression $^{b}$} \\
\hline & & $R^{2}\left(A R^{2}\right)$ & $\beta(95 \% \mathrm{Cl})$ & $R^{2}\left(A R^{2}\right)$ & $\beta(95 \% \mathrm{Cl})$ & $R^{2}\left(A R^{2}\right)$ & $\beta(95 \% \mathrm{Cl})$ & $R^{2}\left(A R^{2}\right)$ & $\beta(95 \% \mathrm{Cl})$ \\
\hline \multicolumn{10}{|c|}{ Knowledge of COVID-19 } \\
\hline \multicolumn{10}{|c|}{ Route of transmission } \\
\hline \multicolumn{10}{|l|}{ Droplets } \\
\hline Agree & $920(99.35)$ & & $\begin{array}{c}0.002(-0.06 \\
\text { to } 0.07)\end{array}$ & & $\begin{array}{l}0.01(-0.06 \\
\text { to } 0.07)\end{array}$ & & $\begin{array}{c}-0.01(-0.08 \\
\text { to } 0.05)\end{array}$ & & $\begin{array}{c}0.01(-0.05 \text { to } \\
0.08)\end{array}$ \\
\hline Disagree & $2(0.22)$ & $<0.001$ (- & $\begin{array}{c}-0.02(-1.41 \\
\text { to } 1.36)\end{array}$ & $<0.001$ & $\begin{array}{c}-0.26(-1.60 \\
\text { to } 1.08)\end{array}$ & 0.001 & $\begin{array}{l}-0.61(-1.71 \\
\text { to } 0.48)\end{array}$ & $<0.001$ & $\begin{array}{c}-0.37(-1.66 \text { to } \\
0.91)\end{array}$ \\
\hline $\begin{array}{c}\text { Do not } \\
\text { know }\end{array}$ & $\begin{array}{c}4 \\
(0.43) \\
\end{array}$ & $0.001)$ & Ref. & $(-0.001)$ & Ref. & $\begin{array}{c}<0.001 \\
1\end{array}$ & Ref. & $(-0.001)$ & Ref. \\
\hline \multicolumn{10}{|c|}{ Contact with contaminated objects } \\
\hline Agree & 797 (86.97) & & $\begin{array}{c}-0.01(-0.08 \\
\text { to } 0.05)\end{array}$ & & $\begin{array}{c}-0.04(-0.10 \\
\text { to } 0.03)\end{array}$ & & $\begin{array}{c}-0.02(-0.09 \\
\text { to } 0.05)\end{array}$ & & $\begin{array}{c}-0.02(-0.09 \text { to } \\
0.05)\end{array}$ \\
\hline Disagree & $63(6.80)$ & $\begin{array}{l}0.005 \\
(0.004)\end{array}$ & $\begin{array}{c}-0.18 *(- \\
0.36 \text { to }- \\
0.01)\end{array}$ & $\begin{array}{c}0.002 \\
(0.001)\end{array}$ & $\begin{array}{c}-0.11(-0.29 \\
\text { to } 0.06)\end{array}$ & $\begin{array}{c}0.005 \\
(0.004)\end{array}$ & $\begin{array}{l}-0.20 *(- \\
0.37 \text { to }- \\
0.03)\end{array}$ & $\begin{array}{c}0.001 \\
(<0.001)\end{array}$ & $\begin{array}{c}-0.10(-0.28 \text { to } \\
0.07)\end{array}$ \\
\hline $\begin{array}{l}\text { Do not } \\
\text { know }\end{array}$ & $\begin{array}{c}66 \\
(7.13) \\
\end{array}$ & & Ref. & & Ref. & & Ref. & & Ref. \\
\hline \multicolumn{10}{|l|}{ Airborne } \\
\hline Agree & $507(54.75)$ & & $\begin{array}{c}<0.001(- \\
0.08 \text { to } \\
0.08)\end{array}$ & & $\begin{array}{c}0.04(-0.04 \\
\text { to }-0.12)\end{array}$ & & $\begin{array}{l}0.04(-0.04 \\
\text { to } 0.12)\end{array}$ & & $\begin{array}{c}0.04(-0.04 \text { to } \\
0.12)\end{array}$ \\
\hline Disagree & $265(28.62)$ & $\begin{array}{c}0.007 \\
(0.007)\end{array}$ & $\begin{array}{c}-0.11 *(- \\
0.21 \text { to }- \\
0.02)\end{array}$ & $\begin{array}{c}0.002 \\
(0.001)\end{array}$ & $\begin{array}{l}0.06(-0.04 \\
\text { to } 0.16)\end{array}$ & $\begin{array}{l}<0.001 \\
(-0.001)\end{array}$ & $\begin{array}{l}0.04(-0.06 \\
\text { to } 0.13)\end{array}$ & $\begin{array}{c}0.001 \\
(0.001)\end{array}$ & $\begin{array}{c}0.07(-0.03 \text { to } \\
0.16)\end{array}$ \\
\hline $\begin{array}{l}\text { Do not } \\
\text { know }\end{array}$ & $154(16.63)$ & & Ref. & & Ref. & & Ref. & & Ref. \\
\hline \multicolumn{10}{|c|}{ Have you heard that the number of infected COVID-19 individuals has increased? } \\
\hline Heard & $923(99.68)$ & $\begin{array}{c}0.005 \\
(0.004)\end{array}$ & $\begin{array}{l}0.07 *(0.01 \\
\text { to } 0.14)\end{array}$ & $\begin{array}{l}0.001(- \\
0.001)\end{array}$ & $\begin{array}{c}-0.02(-0.09 \\
\text { to } 0.04)\end{array}$ & $\begin{array}{c}0.002 \\
(<0.001 \\
)\end{array}$ & $\begin{array}{l}-0.04(-0.10 \\
\text { to } 0.02)\end{array}$ & $\begin{array}{c}0.001 \\
(<0.001)\end{array}$ & $\begin{array}{c}0.02 \\
(-0.09 \text { to } 0.04)\end{array}$ \\
\hline Not heard & $3(0.32)$ & & Ref. & & Ref. & & Ref. & & Ref. \\
\hline \multicolumn{10}{|c|}{ Have you heard that the number of COVID-19 deaths has increased? } \\
\hline Heard & $917(99.03)$ & $\begin{array}{c}0.012 \\
(0.012)\end{array}$ & $\begin{array}{c}0.11^{* * *} \\
(0.05 \text { to } \\
0.18)\end{array}$ & $\begin{array}{l}<0.001 \\
(-0.001)\end{array}$ & $\begin{array}{l}-0.02(-0.08 \\
\text { to } 0.05)\end{array}$ & $\begin{array}{l}<0.001 \\
(-0.001)\end{array}$ & $\begin{array}{l}-0.01(-0.07 \\
\text { to } 0.06)\end{array}$ & $\begin{array}{c}0.001 \\
(<0.001)\end{array}$ & $\begin{array}{c}-0.03(-0.09 \text { to } \\
0.04)\end{array}$ \\
\hline Not heard & $9(0.97)$ & & Ref. & & Ref. & & Ref. & & Ref. \\
\hline \multicolumn{10}{|c|}{ Have you heard that the number of individuals that have recovered from COVID-19 infection has increased? } \\
\hline $\begin{array}{c}\text { Heard } \\
\text { Not heard }\end{array}$ & $\begin{array}{l}649(70.09) \\
277(29.91)\end{array}$ & $\begin{array}{c}0.003 \\
(0.002)\end{array}$ & $\begin{array}{c}-0.06(-0.12 \\
\text { to } 0.01) \\
\text { Ref. }\end{array}$ & $\begin{array}{c}0.003 \\
(0.002)\end{array}$ & $\begin{array}{c}0.05(-0.01 \\
\text { to } 0.12) \\
\text { Ref. }\end{array}$ & $\begin{array}{c}0.003 \\
(0.002)\end{array}$ & $\begin{array}{c}0.05(-0.01 \\
\text { to } 0.12) \\
\text { Ref. }\end{array}$ & $\begin{array}{c}0.003 \\
(0.002)\end{array}$ & $\begin{array}{c}0.06(-0.01 \text { to } \\
0.12) \\
\text { Ref. }\end{array}$ \\
\hline \multicolumn{10}{|c|}{ The main source of health information } \\
\hline Internet & $648(69.98)$ & & $\begin{array}{c}0.07(-0.002 \\
\text { to } 0.15)\end{array}$ & & $\begin{array}{l}0.01(-0.06 \\
\text { to } 0.09)\end{array}$ & & $\begin{array}{l}0.03(-0.04 \\
\text { to } 0.10)\end{array}$ & & $\begin{array}{c}-0.01(-0.09 \text { to } \\
0.06)\end{array}$ \\
\hline Television & $194(20.95)$ & & $\begin{array}{c}0.16^{* *} \\
(0.03 \text { to } \\
0.29)\end{array}$ & & $\begin{array}{c}-0.03(-0.15 \\
\text { to } 0.10)\end{array}$ & & $\begin{array}{l}-0.03(-0.16 \\
\text { to } 0.10)\end{array}$ & & $\begin{array}{c}-0.07(-0.20 \text { to } \\
0.05)\end{array}$ \\
\hline Radio & $19(2.05)$ & $\begin{array}{c}0.002 \\
(0.001)\end{array}$ & $\begin{array}{c}0.01(-0.25 \\
\text { to } 0.27)\end{array}$ & $\begin{array}{l}<0.001 \\
(-0.001)\end{array}$ & $\begin{array}{c}0.13(-0.13 \\
\text { to } 0.39)\end{array}$ & $\begin{array}{l}<0.001 \\
(0.001)\end{array}$ & $\begin{array}{l}0.15(-0.11 \\
\text { to } 0.41)\end{array}$ & $\begin{array}{c}<0.001 \\
(-0.001)\end{array}$ & $\begin{array}{c}0.05(-0.21 \text { to } \\
0.31)\end{array}$ \\
\hline $\begin{array}{l}\text { Family } \\
\text { members }\end{array}$ & $24(2.59)$ & & $\begin{array}{c}0.22(-0.03 \\
\text { to } 0.46)\end{array}$ & & $\begin{array}{l}0.13(-0.12 \\
\text { to } 0.38)\end{array}$ & & $\begin{array}{l}0.12(-0.13 \\
\text { to } 0.37)\end{array}$ & & $\begin{array}{c}-0.02(-0.27 \text { to } \\
0.23)\end{array}$ \\
\hline $\begin{array}{c}\text { Other } \\
\text { sources }\end{array}$ & $41(4.43)$ & & Ref. & & Ref. & & Ref. & & Ref. \\
\hline
\end{tabular}


Satisfaction with the amount of health information available about COVID-19

\begin{tabular}{|c|c|c|c|c|c|c|c|c|c|}
\hline $\begin{array}{c}\text { Very } \\
\text { satisfied }\end{array}$ & 179 (19.33) & & $\begin{array}{c}-0.06(-0.18 \\
\text { to } 0.06)\end{array}$ & & $\begin{array}{c}0.10(-0.02 \\
\text { to } 0.22)\end{array}$ & & $\begin{array}{c}-0.002(- \\
0.13 \text { to } \\
0.14)\end{array}$ & & $\begin{array}{c}0.01(-0.12 \text { to } \\
0.13)\end{array}$ \\
\hline $\begin{array}{c}\text { Somewhat } \\
\text { satisfied }\end{array}$ & $\begin{array}{c}304 \\
(32.83)\end{array}$ & $\begin{array}{c}0.003 \\
(0.002)\end{array}$ & $\begin{array}{c}0.03(-0.07 \\
\text { to } 0.13)\end{array}$ & $\begin{array}{c}0.002 \\
(0.001)\end{array}$ & $\begin{array}{c}0.10(-0.002 \\
\text { to } 0.20)\end{array}$ & $\begin{array}{c}0.003 \\
(0.002)\end{array}$ & $\begin{array}{c}0.03(-0.07 \\
\text { to } 0.13)\end{array}$ & $\begin{array}{c}0.003 \\
(0.002)\end{array}$ & $\begin{array}{c}0.05(-0.06 \text { to } \\
0.15)\end{array}$ \\
\hline $\begin{array}{l}\text { Not very } \\
\text { satisfied }\end{array}$ & $293(30.56$ & & $\begin{array}{c}0.08(-0.02 \\
\text { to } 0.19)\end{array}$ & & $\begin{array}{c}0.09(-0.01 \\
\text { to } 0.19)\end{array}$ & & $\begin{array}{c}0.03(-0.07 \\
\text { to } 0.14)\end{array}$ & & $\begin{array}{c}0.03(-0.07 \text { to } \\
0.14)\end{array}$ \\
\hline $\begin{array}{c}\text { Not satisfied } \\
\text { at all }\end{array}$ & $83(8.96)$ & & $\begin{array}{c}0.15(-0.01 \\
\text { to } 0.31)\end{array}$ & & $\begin{array}{c}0.02(-0.14 \\
\text { to } 0.17)\end{array}$ & & $\begin{array}{c}-0.12(-0.27 \\
\text { to } 0.04)\end{array}$ & & $\begin{array}{c}-0.10(-0.25 \text { to } \\
0.06)\end{array}$ \\
\hline $\begin{array}{l}\text { Do not } \\
\text { know }\end{array}$ & 77 (8.32) & & Ref. & & Ref. & & Ref. & & Ref. \\
\hline
\end{tabular}

Concerns about COVID-19

\begin{tabular}{|c|c|c|c|c|c|c|c|c|c|}
\hline \multicolumn{10}{|c|}{ Level of confidence in own doctor's ability to diagnose or recognize } \\
\hline $\begin{array}{c}\text { Very } \\
\text { confident }\end{array}$ & $190(20.52)$ & & $\begin{array}{c}0.08(-0.03 \\
\text { to } 0.19)\end{array}$ & & $\begin{array}{c}0.01(0.06 \text { to } \\
-0.11)\end{array}$ & & $\begin{array}{c}-0.03(-0.14 \\
\text { to } 0.08)\end{array}$ & & $\begin{array}{c}-0.004(-0.12 \\
\text { to } 0.11)\end{array}$ \\
\hline $\begin{array}{c}\text { Somewhat } \\
\text { confident }\end{array}$ & $304(32.83)$ & & $\begin{array}{c}0.13^{* *} \\
(0.04 \text { to } \\
0.23)\end{array}$ & & $\begin{array}{c}0.04(-0.05 \\
\text { to } 0.14)\end{array}$ & & $\begin{array}{c}0.03(-0.06 \\
\text { to } 0.13)\end{array}$ & & $\begin{array}{c}0.04(-0.06 \text { to } \\
0.13)\end{array}$ \\
\hline $\begin{array}{l}\text { Not very } \\
\text { confident }\end{array}$ & $223(24.08)$ & $\begin{array}{c}0.03 \\
(0.03)\end{array}$ & $\begin{array}{c}0.24 * * * \\
(0.14 \text { to } \\
0.35)\end{array}$ & $\begin{array}{c}0.001 \\
(<0.001)\end{array}$ & $\begin{array}{c}0.04(-0.06 \\
\text { to } 0.15)\end{array}$ & $\begin{array}{c}<0.001 \\
(-0.001)\end{array}$ & $\begin{array}{c}-0.01(-0.12 \\
\text { to } 0.09)\end{array}$ & $\begin{array}{c}0.001(- \\
0.003)\end{array}$ & $\begin{array}{c}0.03(-0.08 \text { to } \\
0.14)\end{array}$ \\
\hline $\begin{array}{l}\text { Not at all } \\
\text { confident }\end{array}$ & $92(9.94)$ & & $\begin{array}{c}0.22 * * * \\
(0.08 \text { to } \\
0.35)\end{array}$ & & $\begin{array}{l}0.01(-0.12 \\
\text { to } 0.15)\end{array}$ & & $\begin{array}{c}-0.04(-0.18 \\
\text { to } 0.10)\end{array}$ & & $\begin{array}{c}0.04(-0.10 \text { to } \\
0.17)\end{array}$ \\
\hline $\begin{array}{l}\text { Do not } \\
\text { know }\end{array}$ & $117(12.63)$ & & Ref. & & Ref. & & Ref. & & Ref. \\
\hline \multicolumn{10}{|c|}{ Likelihood of contracting COVID-19 during the current outbreak } \\
\hline Very likely & $628(67.82)$ & & $\begin{array}{c}0.10^{* *} \\
(0.02 \text { to }- \\
0.17)\end{array}$ & & $\begin{array}{c}0.01(-0.06 \\
\text { to } 0.09)\end{array}$ & & $\begin{array}{c}-0.004(- \\
0.08 \text { to } \\
0.07)\end{array}$ & & $\begin{array}{c}0.02(-0.06 \text { to } \\
0.09)\end{array}$ \\
\hline $\begin{array}{l}\text { Somewhat } \\
\text { likely }\end{array}$ & $190(20.52)$ & & $\begin{array}{c}-0.004(- \\
0.14 \text { to } \\
0.13)\end{array}$ & & $\begin{array}{c}0.02(-0.11 \\
\text { to } 0.16)\end{array}$ & & $\begin{array}{c}0.01(-0.13 \\
\text { to } 0.14)\end{array}$ & & $\begin{array}{c}0.03(-0.10 \text { to } \\
0.17)\end{array}$ \\
\hline $\begin{array}{l}\text { Not very } \\
\text { likely }\end{array}$ & $56(6.05)$ & $\begin{array}{c}0.05 \\
(0.05)\end{array}$ & $\begin{array}{c}-0.24 *(- \\
0.44 \text { do- } \\
0.03)\end{array}$ & $\begin{array}{c}<0.001 \\
(-0.001)\end{array}$ & $\begin{array}{c}-0.12(-0.33 \\
\text { to } 0.10)\end{array}$ & $\begin{array}{c}<0.001 \\
(-0.001)\end{array}$ & $\begin{array}{c}-0.19(-0.41 \\
\text { to } 0.02)\end{array}$ & $\begin{array}{c}0.001 \\
(<0.001)\end{array}$ & $\begin{array}{c}-0.19(-0.40 \text { to } \\
0.02)\end{array}$ \\
\hline $\begin{array}{l}\text { Not likely at } \\
\text { all }\end{array}$ & $22(2.38)$ & & $\begin{array}{c}-0.13(-0.40 \\
\text { to } 0.16)\end{array}$ & & $\begin{array}{l}0.16(-0.12 \\
\text { to } 0.44)\end{array}$ & & $\begin{array}{c}0.12(-0.16 \\
\text { to } 0.40)\end{array}$ & & $\begin{array}{c}0.12(-0.16 \text { to } \\
0.40)\end{array}$ \\
\hline $\begin{array}{l}\text { Do not } \\
\text { know }\end{array}$ & $30(3.24)$ & & Ref. & & Ref. & & Ref. & & Ref. \\
\hline \multicolumn{10}{|c|}{ Likelihood of survival if infected with COVID-19 } \\
\hline Very likely & $496(53.56)$ & & $\begin{array}{c}-0.13^{* *}(- \\
0.22 \text { to - } \\
0.05)\end{array}$ & & $\begin{array}{c}0.004(-0.08 \\
\text { to } 0.09)\end{array}$ & & $\begin{array}{c}-0.01(-0.09 \\
\text { to } 0.07)\end{array}$ & & $\begin{array}{c}-0.001(-0.09 \\
\text { to } 0.07)\end{array}$ \\
\hline $\begin{array}{l}\text { Somewhat } \\
\text { likely }\end{array}$ & $280(30.24)$ & & $\begin{array}{c}-0.03(-0.13 \\
\text { to } 0.08)\end{array}$ & & $\begin{array}{c}0.03(-0.07 \\
\text { to } 0.14)\end{array}$ & & $\begin{array}{c}0.01(-0.10 \\
\text { to }-0.12)\end{array}$ & & $\begin{array}{c}0.002(-0.10 \text { to } \\
0.11)\end{array}$ \\
\hline $\begin{array}{l}\text { Not very } \\
\text { likely }\end{array}$ & $63(6.80)$ & $\begin{array}{c}0.032 \\
(0.031)\end{array}$ & $\begin{array}{c}0.21^{* *} \\
(0.05 \text { to } \\
0.38)\end{array}$ & $\begin{array}{c}<0.001 \\
(-0.001)\end{array}$ & $\begin{array}{c}0.02(-0.15 \\
\text { to } 0.19)\end{array}$ & $\begin{array}{c}0.001 \\
(<0.001 \\
)\end{array}$ & $\begin{array}{c}0.07(-0.09 \\
\text { to } 0.25)\end{array}$ & $\begin{array}{c}<0.001 \\
(-0.001)\end{array}$ & $\begin{array}{c}-0.01(-0.18 \text { to } \\
0.17)\end{array}$ \\
\hline $\begin{array}{c}\text { Not likely at } \\
\text { all }\end{array}$ & $15(1.62)$ & & $\begin{array}{c}0.15(-0.06 \\
\text { to } 0.36)\end{array}$ & & $\begin{array}{c}-0.002(-0.22 \\
\text { to } 0.21)\end{array}$ & & $\begin{array}{c}-0.08(-0.29 \\
\text { to } 0.14)\end{array}$ & & $\begin{array}{c}-0.04(-0.26 \text { to } \\
0.17)\end{array}$ \\
\hline $\begin{array}{c}\text { Do not } \\
\text { know }\end{array}$ & $72(7.78)$ & & Ref. & & Ref. & & Ref. & & Ref. \\
\hline \multicolumn{10}{|c|}{ Concerns about other family members getting COVID-19 infection } \\
\hline $\begin{array}{c}\text { Very } \\
\text { worried }\end{array}$ & $527(56.91)$ & & $\begin{array}{c}0.10 *(0.01 \\
\text { to } 0.18)\end{array}$ & & $\begin{array}{c}0.07(-0.02 \\
\text { to } 0.15)\end{array}$ & & $\begin{array}{c}0.07(-0.01 \\
\text { to } 0.16)\end{array}$ & & $\begin{array}{c}0.07(-0.02 \text { to } \\
0.15)\end{array}$ \\
\hline $\begin{array}{c}\text { Somewhat } \\
\text { worried }\end{array}$ & $261(28.83)$ & & $\begin{array}{c}0.03(-0.09 \\
\text { to } 0.15)\end{array}$ & & $\begin{array}{c}0.08(-0.04 \\
\text { to } 0.20)\end{array}$ & & $\begin{array}{c}0.10(-0.02 \\
\text { to } 0.22)\end{array}$ & & $\begin{array}{c}0.08(-0.04 \text { to } \\
0.20)\end{array}$ \\
\hline $\begin{array}{l}\text { Not very } \\
\text { worried }\end{array}$ & $70(7.56)$ & $\begin{array}{c}0.174 \\
(0.174)\end{array}$ & $\begin{array}{c}-0.12(-0.34 \\
\text { to } 0.11)\end{array}$ & $\begin{array}{l}<0.001 \\
(0.001)\end{array}$ & $\begin{array}{c}0.16(-0.07 \\
\text { to } 0.39)\end{array}$ & $\begin{array}{c}<0.001 \\
(-0.001)\end{array}$ & $\begin{array}{c}0.17(-0.05 \\
\text { to } 0.40)\end{array}$ & $\begin{array}{c}<0.001 \\
(-0.001)\end{array}$ & $\begin{array}{c}0.14(-0.08 \text { to } \\
0.37)\end{array}$ \\
\hline $\begin{array}{c}\text { Not worried } \\
\text { at all }\end{array}$ & $55(5.94)$ & & $\begin{array}{c}-0.20(-0.44 \\
\text { to } 0.06)\end{array}$ & & $\begin{array}{c}0.23(-0.02 \\
\text { to } 0.48)\end{array}$ & & $\begin{array}{c}0.22(-0.03 \\
\text { to } 0.47)\end{array}$ & & $\begin{array}{c}0.22(-0.03 \text { to } \\
0.47)\end{array}$ \\
\hline $\begin{array}{c}\text { Do not have } \\
\text { family } \\
\text { members }\end{array}$ & $7(0.76)$ & & Ref. & & Ref. & & Ref. & & Ref. \\
\hline \multicolumn{10}{|c|}{ Concerns about a child younger than 16 years getting COVID-19 infection } \\
\hline $\begin{array}{c}\text { Very } \\
\text { worried }\end{array}$ & 346 (37.67) & & $\begin{array}{l}022^{* * *} \\
(0.15 \text { to }\end{array}$ & & $\begin{array}{c}-0.001(-0.08 \\
\text { to } 0.08)\end{array}$ & & $\begin{array}{l}-0.001 \text { (- } \\
0.08 \text { to }\end{array}$ & & $\begin{array}{c}-0.01(-0.09 \text { to } \\
0.07)\end{array}$ \\
\hline
\end{tabular}




\begin{tabular}{|c|c|c|c|c|c|c|c|c|c|}
\hline & & & $0.30)$ & & & & 0.07) & & \\
\hline $\begin{array}{c}\text { Somewhat } \\
\text { worried }\end{array}$ & $163(17.60)$ & & $\begin{array}{c}-0.05(-0.15 \\
\text { to } 0.04)\end{array}$ & & $\begin{array}{c}-0.03(-0.13 \\
\text { d0 } 0.06)\end{array}$ & & $\begin{array}{c}0.01(-0.08 \\
\text { to } 0.10)\end{array}$ & & $\begin{array}{c}-0.02(-0.11 \text { to } \\
0.07)\end{array}$ \\
\hline $\begin{array}{l}\text { Not very } \\
\text { worried }\end{array}$ & $86(9.29)$ & $\begin{array}{c}0.025 \\
(0.024)\end{array}$ & $\begin{array}{c}-0.14^{* *}(- \\
0.24 \text { to }- \\
0.04)\end{array}$ & $\begin{array}{l}<0.001 \\
(-0.001)\end{array}$ & $\begin{array}{c}-0.02(-0.12 \\
\text { to } 0.08)\end{array}$ & $\begin{array}{l}<0.001 \\
(-0.001)\end{array}$ & $\begin{array}{c}-0.04(-0.14 \\
\text { to } 0.06)\end{array}$ & $\begin{array}{l}<0.001 \\
(-0.001)\end{array}$ & $\begin{array}{c}-0.02(-0.12 \text { to } \\
0.08)\end{array}$ \\
\hline $\begin{array}{c}\text { Not worried } \\
\text { at all }\end{array}$ & $32(3.46)$ & & $\begin{array}{c}-0.24^{* * *}(- \\
0.35 \text { to }- \\
0.14)\end{array}$ & & $\begin{array}{c}0.003(-0.11 \\
\text { to } 0.11)\end{array}$ & & $\begin{array}{c}-0.02(-0.12 \\
\text { to } 0.09)\end{array}$ & & $\begin{array}{c}0.01 \text { (- }-0.10 \text { to } \\
0.12)\end{array}$ \\
\hline $\begin{array}{l}\text { Do not have } \\
\text { children }\end{array}$ & 299 (32.29) & & Ref. & & Ref. & & Ref. & & Ref. \\
\hline
\end{tabular}

$* p<0,05 ; * * p<0,01 ; p<0,001$.

$\mathrm{AR}^{2}$, Adjusted R-Squared $\mathrm{Cl}$, confidence interval; N, number; Ref., reference.

${ }^{a}$ Posttraumatic stress symptoms were measured using the Impact of Event Scale-Revised (IES-R).

${ }^{\mathrm{b}}$ Depression, Anxiety and Stress were measured using the Depression Anxiety Stress Scale (DASS-21). 
Table 5. Association between precautionary measures in the past 14 days, additional health information required and the posttraumatic stress symptoms related to the COVID-19 outbreak as well as adverse mental health status during the pandemic $(\mathrm{N}=926)$.

\begin{tabular}{|c|c|c|c|c|c|c|c|c|c|}
\hline \multirow[b]{2}{*}{ Variables } & \multirow[b]{2}{*}{$\mathrm{N}(\%)$} & \multicolumn{2}{|c|}{ PTSS $^{\text {a }}$} & \multicolumn{2}{|c|}{ Stress $^{b}$} & \multicolumn{2}{|c|}{ Anxiety ${ }^{b}$} & \multicolumn{2}{|c|}{ Depression ${ }^{b}$} \\
\hline & & $R^{2}\left(A R^{2}\right)$ & $\beta(95 \% \mathrm{Cl})$ & $R^{2}\left(A R^{2}\right)$ & $\beta(95 \% \mathrm{Cl})$ & $R^{2}\left(A R^{2}\right)$ & $\beta(95 \% \mathrm{Cl})$ & $R^{2}\left(A R^{2}\right)$ & $\beta(95 \% \mathrm{Cl})$ \\
\hline \multicolumn{10}{|c|}{ Covering mouth when coughing and sneezing } \\
\hline Always & $\begin{array}{c}773 \\
(83.48)\end{array}$ & & $\begin{array}{c}0.06(-0.01 \text { to } \\
0.13)\end{array}$ & & $\begin{array}{c}0.01(-0.06 \\
\text { to } 0.08)\end{array}$ & & $\begin{array}{c}0.02(-0.04 \\
\text { to } 0.09)\end{array}$ & & $\begin{array}{c}-0.02(-0.09 \\
\text { to } 0.05)\end{array}$ \\
\hline $\begin{array}{l}\text { Most of the } \\
\text { time }\end{array}$ & $\begin{array}{c}118 \\
(12.74)\end{array}$ & & $\begin{array}{c}0.11(-0.06 \text { to } \\
0.29)\end{array}$ & & $\begin{array}{c}-0.01(-0.18 \\
\text { to } 0.17)\end{array}$ & & $\begin{array}{c}0.02(-0.15 \\
\text { to } 0.20)\end{array}$ & & $\begin{array}{c}-0.11(-0.29 \\
\text { to } 0.06)\end{array}$ \\
\hline Sometimes & $\begin{array}{c}17 \\
(1.84)\end{array}$ & $\begin{array}{c}0.001 \\
(<0.001)\end{array}$ & $\begin{array}{c}0.14(-0.26 \text { to } \\
0.54)\end{array}$ & $\begin{array}{c}0.002 \\
(0.001)\end{array}$ & $\begin{array}{c}-0.10(-0.51 \\
\text { to } 0.30)\end{array}$ & $\begin{array}{c}<0.001(- \\
0.001)\end{array}$ & $\begin{array}{c}-0.06(-0.46 \\
\text { to } 0.34)\end{array}$ & $\begin{array}{c}0.004 \\
(0.003)\end{array}$ & $\begin{array}{c}-0.26(-0.64 \\
\text { to } 0.12)\end{array}$ \\
\hline Occasionally & $7(0.76)$ & & $\begin{array}{c}0.27(-0.23 \text { to } \\
0.78)\end{array}$ & & $\begin{array}{c}0.05(-0.48 \\
\text { to } 0.58)\end{array}$ & & $\begin{array}{l}0.35(-0.14 \\
\text { to } 0.85)\end{array}$ & & $\begin{array}{c}-0.07(-0.60 \\
\text { to } 0.46)\end{array}$ \\
\hline Never & $\begin{array}{c}11 \\
(1.19)\end{array}$ & & Ref. & & Ref. & & Ref. & & Ref. \\
\hline \multicolumn{10}{|c|}{ Avoidance of sharing utensils } \\
\hline Always & $\begin{array}{c}591 \\
(63.82)\end{array}$ & & $\begin{array}{c}0.11^{*}(0.03 \text { to } \\
0.18)\end{array}$ & & $\begin{array}{c}0.01(-0.07 \\
\text { to } 0.08)\end{array}$ & & $\begin{array}{c}0.01(-0.07 \\
\text { to } 0.08)\end{array}$ & & $\begin{array}{c}0.01(-0.06 \\
\text { to } 0.09)\end{array}$ \\
\hline $\begin{array}{l}\text { Most of the } \\
\text { time }\end{array}$ & $\begin{array}{c}189 \\
(20.41)\end{array}$ & & $\begin{array}{c}0.20^{* *}(0.08 \text { to } \\
0.32)\end{array}$ & & $\begin{array}{c}0.07(-0.06 \\
\text { to } 0.19)\end{array}$ & & $\begin{array}{c}0.05(-0.07 \\
\text { to } 0.18)\end{array}$ & & $\begin{array}{c}0.07(-0.06 \\
\text { to } 0.20)\end{array}$ \\
\hline Sometimes & $\begin{array}{c}45 \\
(4.86)\end{array}$ & $\begin{array}{c}0.02 \\
(0.001)\end{array}$ & $\begin{array}{c}0.11(-0.08 \text { to } \\
0.31)\end{array}$ & $\begin{array}{l}0.001(- \\
0.001)\end{array}$ & $\begin{array}{c}0.04(-0.16 \\
\text { to } 0.23)\end{array}$ & $\begin{array}{c}<0.001(- \\
0.001)\end{array}$ & $\begin{array}{c}0.01(-0.19 \\
\text { to } 0.20)\end{array}$ & $\begin{array}{c}0.001 \\
(<0.001)\end{array}$ & $\begin{array}{c}0.06(-0.13 \\
\text { to } 0.26)\end{array}$ \\
\hline Occasionally & $\begin{array}{c}41 \\
(4.43)\end{array}$ & & $\begin{array}{c}0.23 *(0.03 \text { to } \\
0.42)\end{array}$ & & $\begin{array}{c}0.03(-0.17 \\
\text { to } 0.23)\end{array}$ & & $\begin{array}{c}0.03(-0.17 \\
\text { to } 0.23)\end{array}$ & & $\begin{array}{c}0.01(-0.19 \\
\text { to } 0.21)\end{array}$ \\
\hline Never & $\begin{array}{c}60 \\
(6.48)\end{array}$ & & Ref. & & Ref. & & Ref. & & Ref. \\
\hline \multicolumn{10}{|c|}{ Washing hands with soap and water } \\
\hline Always & $\begin{array}{c}880 \\
(95.03)\end{array}$ & & $\begin{array}{c}0.06(-0.01 \text { to } \\
0.12)\end{array}$ & & $\begin{array}{c}0.03(-0.03 \\
\text { to } 0.10)\end{array}$ & & $\begin{array}{c}0.01(-0.05 \\
\text { to } 0.08)\end{array}$ & & $\begin{array}{c}0.01(-0.05 \\
\text { to } 0.08)\end{array}$ \\
\hline $\begin{array}{l}\text { Most of the } \\
\text { time }\end{array}$ & $\begin{array}{c}38 \\
(4.10)\end{array}$ & & $\begin{array}{c}0.25(-0.07 \text { to } \\
0.57)\end{array}$ & & $\begin{array}{l}0.18(-0.15 \\
\text { to } 0.50)\end{array}$ & & $\begin{array}{l}0.10(-0.23 \\
\text { to } 0.42)\end{array}$ & & $\begin{array}{c}0.09(-0.24 \\
\text { to } 0.42)\end{array}$ \\
\hline Sometimes & $6(0.65)$ & $\begin{array}{l}0.007 \\
(0.006)\end{array}$ & $\begin{array}{c}0.02(-0.98 \text { to } \\
1.02)\end{array}$ & $\begin{array}{c}<0.001(- \\
0.001)\end{array}$ & $\begin{array}{c}0.32(-0.62 \\
\text { to } 1.27)\end{array}$ & $\begin{array}{c}<0.001(- \\
0.001)\end{array}$ & $\begin{array}{c}-0.03(-1.02 \\
\text { to } 0.97)\end{array}$ & $\begin{array}{c}<0.001(- \\
0.001)\end{array}$ & $\begin{array}{c}0.17(-0.81 \\
\text { to } 1.16)\end{array}$ \\
\hline $\begin{array}{l}\text { Occasionally } \\
\text { or Never }\end{array}$ & $2(0.22)$ & & Ref. & & Ref. & & Ref. & & Ref. \\
\hline \multicolumn{10}{|c|}{ Washing hands immediately after coughing, rubbing nose, or sneezing } \\
\hline Always & $\begin{array}{c}439 \\
(47.41)\end{array}$ & & $\begin{array}{c}0.16^{* * *}(0.07 \text { to } \\
0.25)\end{array}$ & & $\begin{array}{c}0.02(-0.07 \\
\text { to } 0.11)\end{array}$ & & $\begin{array}{l}0.04(-0.05 \\
\text { to } 0.13)\end{array}$ & & $\begin{array}{c}0.004 \text { (- } \\
0.09 \text { to } \\
0.09)\end{array}$ \\
\hline $\begin{array}{l}\text { Most of the } \\
\text { time }\end{array}$ & $\begin{array}{c}286 \\
(30.89)\end{array}$ & & $\begin{array}{c}0.16^{* *}(0.05 \text { to } \\
0.27)\end{array}$ & & $\begin{array}{c}0.04(-0.07 \\
\text { to } 0.15)\end{array}$ & & $\begin{array}{l}0.07(-0.04 \\
\text { to } 0.18)\end{array}$ & & $\begin{array}{c}0.03(-0.08 \\
\text { to } 0.14)\end{array}$ \\
\hline Sometimes & $\begin{array}{c}112 \\
(12.10)\end{array}$ & $\begin{array}{c}0.007 \\
(0.006)\end{array}$ & $\begin{array}{c}0.16(-0.01 \text { to } \\
0.32)\end{array}$ & $\begin{array}{l}<0.001(- \\
0.001)\end{array}$ & $\begin{array}{c}0.01(-0.15 \\
\text { to } 0.18)\end{array}$ & $\begin{array}{l}<0.001(- \\
0.001)\end{array}$ & $\begin{array}{l}0.04(-0.13 \\
\text { to } 0.20)\end{array}$ & $\begin{array}{l}<0.001(- \\
0.001)\end{array}$ & $\begin{array}{c}-0.05(-0.21 \\
\text { to } 0.11)\end{array}$ \\
\hline Occasionally & $\begin{array}{c}51 \\
(5.51)\end{array}$ & & $\begin{array}{c}0.07(-0.15 \text { to } \\
0.28)\end{array}$ & & $\begin{array}{c}0.05(-0.16 \\
\text { to } 0.26)\end{array}$ & & $\begin{array}{c}0.09(-0.12 \\
\text { to } 0.30)\end{array}$ & & $\begin{array}{c}0.01(-0.21 \\
\text { to } 0.22)\end{array}$ \\
\hline Never & $\begin{array}{c}38 \\
(4.10) \\
\end{array}$ & & Ref. & & Ref. & & Ref. & & Ref. \\
\hline \multicolumn{10}{|c|}{ Wearing mask regardless of the presence or absence of symptoms } \\
\hline Always & $\begin{array}{c}141 \\
(15.23)\end{array}$ & & $\begin{array}{c}0.19 * * *(0.10 \text { to } \\
0.28)\end{array}$ & & $\begin{array}{c}-0.10^{*}(- \\
0.19 \text { to } \\
0.01)\end{array}$ & & $\begin{array}{c}-0.13^{* *}(- \\
0.22 \text { to }- \\
0.04)\end{array}$ & & $\begin{array}{l}-0.09(-0.18 \\
\text { to } 0.004)\end{array}$ \\
\hline
\end{tabular}




\begin{tabular}{|c|c|c|c|c|c|c|c|c|c|}
\hline $\begin{array}{l}\text { Most of the } \\
\text { time }\end{array}$ & $\begin{array}{c}302 \\
(33.61)\end{array}$ & & $\begin{array}{c}0.19 * * *(0.11 \text { to } \\
0.26)\end{array}$ & & $\begin{array}{c}-0.04(-0.12 \\
\text { to } 0.04)\end{array}$ & & $\begin{array}{c}-0.04(-0.12 \\
\text { to } 0.04)\end{array}$ & & $\begin{array}{c}-0.03(-0.10 \\
\text { to } 0.05)\end{array}$ \\
\hline Sometimes & $\begin{array}{c}89 \\
(9.61)\end{array}$ & $\begin{array}{c}0.016 \\
(0.015)\end{array}$ & $\begin{array}{c}0.06(-0.03 \text { to } \\
0.16)\end{array}$ & $\begin{array}{c}0.002 \\
(0.001)\end{array}$ & $\begin{array}{c}-0.04(-0.14 \\
\text { to } 0.06)\end{array}$ & $\begin{array}{c}0.004 \\
(0.003)\end{array}$ & $\begin{array}{c}-0.05(-0.15 \\
\text { to } 0.05)\end{array}$ & $\begin{array}{c}0.001 \\
(<0.001)\end{array}$ & $\begin{array}{c}-0.01(-0.11 \\
\text { to } 0.09)\end{array}$ \\
\hline Occasionally & $\begin{array}{c}61 \\
(6.59)\end{array}$ & & $\begin{array}{c}0.18 * * *(0.09 \text { to } \\
0.28)\end{array}$ & & $\begin{array}{c}-0.07(-0.16 \\
\text { to } 0.03)\end{array}$ & & $\begin{array}{c}-0.11^{*}(- \\
0.21 \text { to - } \\
0.02)\end{array}$ & & $\begin{array}{c}-0.08(-0.18 \\
\text { to } 0.02)\end{array}$ \\
\hline Never & $\begin{array}{c}333 \\
(35.96)\end{array}$ & & Ref. & & Ref. & & Ref. & & Ref. \\
\hline \multicolumn{10}{|c|}{ Washing hands after touching contaminated objects } \\
\hline Always & $\begin{array}{c}689 \\
(74.41)\end{array}$ & & $\begin{array}{c}0.05(-0.02 \text { to } \\
0.13)\end{array}$ & & $\begin{array}{c}-0.06(-0.13 \\
\text { to } 0.02)\end{array}$ & & $\begin{array}{c}0.01(-0.06 \\
\text { to } 0.09)\end{array}$ & & $\begin{array}{c}-0.08^{*}(- \\
0.15 \text { to - } \\
0.002)\end{array}$ \\
\hline $\begin{array}{l}\text { Most of the } \\
\text { time }\end{array}$ & $\begin{array}{c}161 \\
(17.39)\end{array}$ & & $\begin{array}{c}0.05(-0.10 \text { to } \\
0.20)\end{array}$ & & $\begin{array}{c}-0.13(-0.28 \\
\text { to } 0.02)\end{array}$ & & $\begin{array}{c}0.002(- \\
0.15 \text { to } \\
0.15)\end{array}$ & & $\begin{array}{c}-0.17^{*}(- \\
0.32 \text { to - } \\
0.02)\end{array}$ \\
\hline Sometimes & $\begin{array}{c}49 \\
(5.29)\end{array}$ & $\begin{array}{c}0.014 \\
(0.014)\end{array}$ & $\begin{array}{c}-0.02(-0.28 \text { to } \\
0.24)\end{array}$ & $\begin{array}{c}0.002 \\
(0.001)\end{array}$ & $\begin{array}{c}-0.20(-0.45 \\
\text { to } 0.06)\end{array}$ & $\begin{array}{c}0.002 \\
(0.001)\end{array}$ & $\begin{array}{c}0.02(-0.24 \\
\text { to } 0.28)\end{array}$ & $\begin{array}{c}0.003 \\
(0.002)\end{array}$ & $\begin{array}{c}-0.27^{*}(- \\
0.52 \text { to - } \\
0.02)\end{array}$ \\
\hline Occasionally & $\begin{array}{c}15 \\
(1.62)\end{array}$ & & $\begin{array}{c}-0.04(-0.45 \text { to } \\
0.37)\end{array}$ & & $\begin{array}{c}-0.42 *(- \\
0.79 \text { to - } \\
0.04)\end{array}$ & & $\begin{array}{c}-0.17(-0.57 \\
\text { to } 0.24)\end{array}$ & & $\begin{array}{c}-0.45^{* *}(- \\
0.81 \text { to - } \\
0.08)\end{array}$ \\
\hline Never & $\begin{array}{c}12 \\
(1.30)\end{array}$ & & Ref. & & Ref. & & Ref. & & Ref. \\
\hline \multicolumn{10}{|c|}{ Feeling that too much unnecessary nervousness has been created around the COVID-19 outbreak } \\
\hline Always & $\begin{array}{c}112 \\
(12.10)\end{array}$ & & $\begin{array}{c}-0.10(-0.22 \text { to } \\
0.02)\end{array}$ & & $\begin{array}{c}0.07(-0.05 \\
\text { to } 0.18)\end{array}$ & & $\begin{array}{c}-0.04(-0.16 \\
\text { to } 0.07)\end{array}$ & & $\begin{array}{c}0.08(-0.04 \\
\text { to } 0.19)\end{array}$ \\
\hline $\begin{array}{l}\text { Most of the } \\
\text { time }\end{array}$ & $\begin{array}{c}191 \\
(20.63)\end{array}$ & & $\begin{array}{c}-0.11 *(-0.21 \text { to }- \\
0.01)\end{array}$ & & $\begin{array}{c}0.02(-0.08 \\
\text { to } 0.12)\end{array}$ & & $\begin{array}{c}-0.02(-0.12 \\
\text { to } 0.09)\end{array}$ & & $\begin{array}{c}0.01(-0.09 \\
\text { to } 0.12)\end{array}$ \\
\hline Sometimes & $\begin{array}{c}320 \\
(34.56)\end{array}$ & $\begin{array}{c}0.004 \\
(0.003)\end{array}$ & $\begin{array}{c}-0.09 *(-0.18 \text { to }- \\
0.003)\end{array}$ & $\begin{array}{c}0.001 \\
(<0.001)\end{array}$ & $\begin{array}{c}-0.01(-0.10 \\
\text { to } 0.08)\end{array}$ & $\begin{array}{c}0.001(- \\
0.001)\end{array}$ & $\begin{array}{c}-0.04(-0.13 \\
\text { to } 0.05)\end{array}$ & $\begin{array}{c}<0.001(- \\
0.001)\end{array}$ & $\begin{array}{c}-0.003(- \\
0.09 \text { to } \\
0.09)\end{array}$ \\
\hline Occasionally & $\begin{array}{c}129 \\
(13.93)\end{array}$ & & $\begin{array}{c}-0.13 *(-0.24 \text { to }- \\
0.02)\end{array}$ & & $\begin{array}{c}-0.02(-0.14 \\
\text { to } 0.09)\end{array}$ & & $\begin{array}{c}-0.03(-0.14 \\
\text { to } 0.08)\end{array}$ & & $\begin{array}{c}-0.01(-0.12 \\
\text { to } 0.11)\end{array}$ \\
\hline Never & $\begin{array}{c}174 \\
(18.79)\end{array}$ & & Ref. & & Ref. & & Ref. & & Ref. \\
\hline \multicolumn{10}{|c|}{ Average number of hours staying at home per day to avoid COVID-19 } \\
\hline $0-9$ & $\begin{array}{c}88 \\
(9.50)\end{array}$ & & $\begin{array}{c}-0.13 * * *(-0.21 \\
\text { to }-0.06)\end{array}$ & & $\begin{array}{c}-0.03(-0.10 \\
\text { to } 0.05)\end{array}$ & & $\begin{array}{c}-0.05(-0.12 \\
\text { to } 0.03)\end{array}$ & & $\begin{array}{c}-0.02(-0.09 \\
\text { to } 0.06)\end{array}$ \\
\hline $10-19$ & $\begin{array}{c}225 \\
(24.30)\end{array}$ & $\begin{array}{l}<0.001 \\
(0.001)\end{array}$ & $\begin{array}{c}0.02(-0.04 \text { to } \\
0.09)\end{array}$ & $\begin{array}{c}<0.001(- \\
0.001)\end{array}$ & $\begin{array}{c}-0.02(-0.09 \\
\text { to } 0.05)\end{array}$ & $\begin{array}{c}0.006 \\
(0.005)\end{array}$ & $\begin{array}{c}-0.08 *(- \\
0.15 \text { to - } \\
0.01)\end{array}$ & $\begin{array}{c}0.003 \\
(0.002)\end{array}$ & $\begin{array}{c}-0.06(-0.13 \\
\text { to } 0.01)\end{array}$ \\
\hline $20-24$ & $\begin{array}{c}613 \\
(66.20)\end{array}$ & & Ref. & & Ref. & & Ref. & & Ref. \\
\hline \multicolumn{10}{|c|}{ Need for further health information about the COVID-19 infection } \\
\hline Yes & $\begin{array}{c}621 \\
(67.06)\end{array}$ & $\begin{array}{c}0.063 \\
(0.062)\end{array}$ & $\begin{array}{c}0.25 * *(0.19 \text { to } \\
0.31)\end{array}$ & $\begin{array}{c}0.001 \\
(<0.001)\end{array}$ & $\begin{array}{c}-0.04(-0.10 \\
\text { to } 0.03)\end{array}$ & $\begin{array}{c}<0.001(- \\
0.001)\end{array}$ & $\begin{array}{c}-0.01(-0.08 \\
\text { to } 0.05)\end{array}$ & $0.003(0.02)$ & $\begin{array}{c}-0.06(-0.12 \\
\text { to } 0.01)\end{array}$ \\
\hline No & $\begin{array}{c}305 \\
(32.94)\end{array}$ & & Ref. & & Ref. & & Ref. & & Ref. \\
\hline \multicolumn{10}{|c|}{ Need for details on symptoms of the COVID-19 infection } \\
\hline Yes & $\begin{array}{c}541 \\
(58.41)\end{array}$ & $\begin{array}{c}0.054 \\
(0.053)\end{array}$ & $\begin{array}{c}0.23 * * *(0.17 \text { to } \\
0.30)\end{array}$ & $\begin{array}{c}0.004 \\
(0.003)\end{array}$ & $\begin{array}{c}-0.06(-0.13 \\
\text { to } 0.005)\end{array}$ & $\begin{array}{c}0.004 \\
(0.003)\end{array}$ & $\begin{array}{c}-0.06(-0.13 \\
\text { to } 0.003)\end{array}$ & $\begin{array}{c}0.005 \\
(0.004)\end{array}$ & $\begin{array}{c}-0.07 *(- \\
0.14 \text { to }- \\
0.01)\end{array}$ \\
\hline No & $\begin{array}{c}385 \\
(41.58)\end{array}$ & & Ref. & & Ref. & & Ref. & & Ref. \\
\hline \multicolumn{10}{|c|}{ Need for advice on prevention of the COVID-19 infection } \\
\hline Yes & $\begin{array}{c}372 \\
(40.17)\end{array}$ & $\begin{array}{c}0.058 \\
(0.058)\end{array}$ & $\begin{array}{c}0.24 * * *(0.18 \text { to } \\
0.30)\end{array}$ & $\begin{array}{c}<0.001(- \\
0.001)\end{array}$ & $\begin{array}{c}-0.01(-0.07 \\
\text { to } 0.06)\end{array}$ & $\begin{array}{c}<0.001(- \\
0.001)\end{array}$ & $\begin{array}{c}-0.02(-0.08 \\
\text { to } 0.04)\end{array}$ & $\begin{array}{c}0.001 \\
(<0.001)\end{array}$ & $\begin{array}{c}-0.02(-0.09 \\
\text { to } 0.04)\end{array}$ \\
\hline
\end{tabular}




\begin{tabular}{|c|c|c|c|c|c|c|c|c|c|}
\hline No & $\begin{array}{c}554 \\
(59.83) \\
\end{array}$ & & Ref. & & Ref. & & Ref. & & Ref. \\
\hline \multicolumn{10}{|c|}{ Need for advice on treatment of the COVID-19 infection } \\
\hline Yes & $\begin{array}{c}557 \\
(60.15)\end{array}$ & $\begin{array}{c}0.109 \\
(0.108)\end{array}$ & $\begin{array}{c}0.33 * * *(0.26 \text { to } \\
0.39)\end{array}$ & $\begin{array}{c}<0.001(- \\
0.001)\end{array}$ & $\begin{array}{l}0.01(-0.05 \\
\text { to } 0.07)\end{array}$ & $\begin{array}{l}<0.001 \\
(0.001)\end{array}$ & $\begin{array}{c}0.02(-0.05 \\
\text { to } 0.08)\end{array}$ & $\begin{array}{c}<0.001(- \\
0.001)\end{array}$ & $\begin{array}{c}0.01(-0.05 \\
\text { to } 0.08)\end{array}$ \\
\hline No & $\begin{array}{c}369 \\
(39.85) \\
\end{array}$ & & Ref. & & Ref. & & Ref. & & Ref. \\
\hline \multicolumn{10}{|c|}{ Need for regular updates for the latest information about the COVID-19 infection } \\
\hline Yes & $\begin{array}{c}734 \\
(79.27)\end{array}$ & $\begin{array}{c}0.045 \\
(0.045)\end{array}$ & $\begin{array}{c}0.21 * * *(0.15 \text { to } \\
0.28)\end{array}$ & $\begin{array}{l}<0.001 \\
(0.001)\end{array}$ & $\begin{array}{l}0.01(-0.05 \\
\text { to } 0.08)\end{array}$ & $\begin{array}{c}<0.001(- \\
0.001)\end{array}$ & $\begin{array}{l}0.01(-0.06 \\
\text { to } 0.07)\end{array}$ & $\begin{array}{c}0.001 \\
(<0.001)\end{array}$ & $\begin{array}{c}-0.03(-0.09 \\
\text { to } 0.04)\end{array}$ \\
\hline No & $\begin{array}{c}192 \\
(20.73) \\
\end{array}$ & & Ref. & & Ref. & & Ref. & & Ref. \\
\hline \multicolumn{10}{|c|}{ Need for the latest updates for outbreaks of the COVID-19 infection in the local area } \\
\hline Yes & $\begin{array}{c}786 \\
(84.88)\end{array}$ & $\begin{array}{c}0.052 \\
(0.051)\end{array}$ & $\begin{array}{c}0.23 * * *(0.16 \text { to } \\
0.29)\end{array}$ & $\begin{array}{c}0.001 \\
(<0.001)\end{array}$ & $\begin{array}{c}-0.03(-0.10 \\
\text { to } 0.03)\end{array}$ & $\begin{array}{c}0.001 \\
(<0.001)\end{array}$ & $\begin{array}{c}-0.03(-0.09 \\
\text { to } 0.04)\end{array}$ & $\begin{array}{c}0.002 \\
(0.001)\end{array}$ & $\begin{array}{c}-0.05(-0.11 \\
\text { to } 0.01)\end{array}$ \\
\hline No & $\begin{array}{c}140 \\
(15.12) \\
\end{array}$ & & Ref. & & Ref. & & Ref. & & Ref. \\
\hline \multicolumn{10}{|c|}{ Need for advice for people who may need more tailored information, such as those with pre-existing illnesses } \\
\hline Yes & $\begin{array}{c}575 \\
(62.10)\end{array}$ & $\begin{array}{c}0.063 \\
(0.062)\end{array}$ & $\begin{array}{c}0.25 * * *(0.19 \text { to } \\
0.31)\end{array}$ & $\begin{array}{l}<0.001 \\
(0.001)\end{array}$ & $\begin{array}{c}0.01(-0.06 \\
\text { to } 0.07)\end{array}$ & $\begin{array}{c}<0.001(- \\
0.001)\end{array}$ & $\begin{array}{c}-0.003(- \\
0.07 \text { to } \\
0.06)\end{array}$ & $\begin{array}{c}<0.001(- \\
0.001)\end{array}$ & $\begin{array}{c}-0.02(-0.08 \\
\text { to } 0.05)\end{array}$ \\
\hline No & $\begin{array}{c}351 \\
(37.90) \\
\end{array}$ & & Ref. & & Ref. & & Ref. & & Ref. \\
\hline
\end{tabular}

Need for information on the availability and effectiveness of medicines/vaccines for the COVID-19 infection

\begin{tabular}{|c|c|c|c|c|c|c|c|c|}
\hline 755 & & $0.23^{* * *}(0.17$ to & & $-0.01(-0.07$ & & $0.03(-0.03$ & & $-0.01(-0.08$ \\
\hline (81.53) & $\begin{array}{c}0.052 \\
(0.051)\end{array}$ & $0.29)$ & $\begin{array}{c}<0.001(- \\
0.001)\end{array}$ & to 0.06 ) & $\begin{array}{c}0.001 \\
(<0.001)\end{array}$ & to 0.09 ) & $\begin{array}{c}<0.001(- \\
0.001)\end{array}$ & to 0.05 ) \\
\hline 171 & & Ref. & & Ref. & & Ref. & & Ref. \\
\hline
\end{tabular}

Need for the latest updates on the number of people infected with COVID-19 and their location

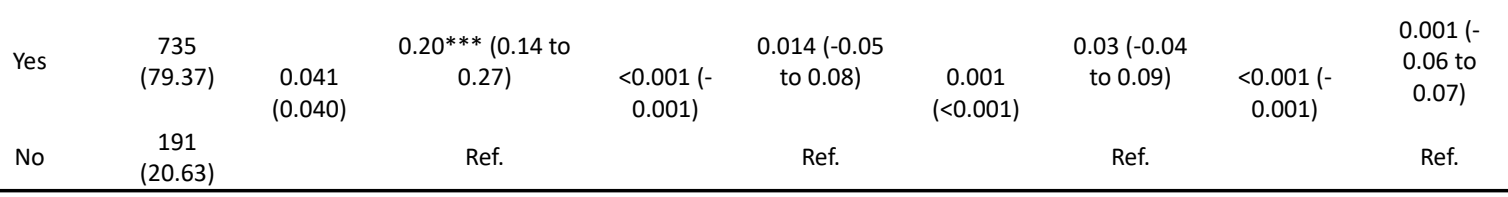

Need for travel advice for the COVID-19 epidemic

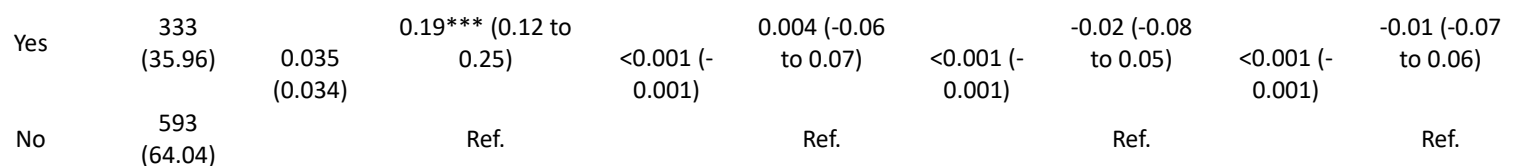

Need for updates on the routes of transmission of COVID-19

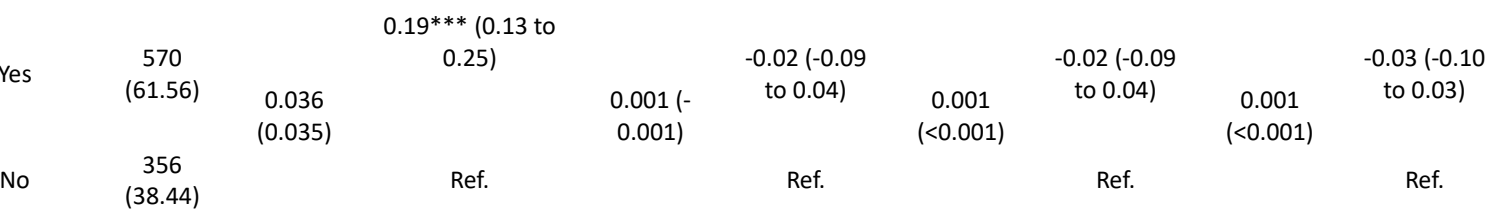

Need for updates on how other countries handle the COVID-19 outbreak

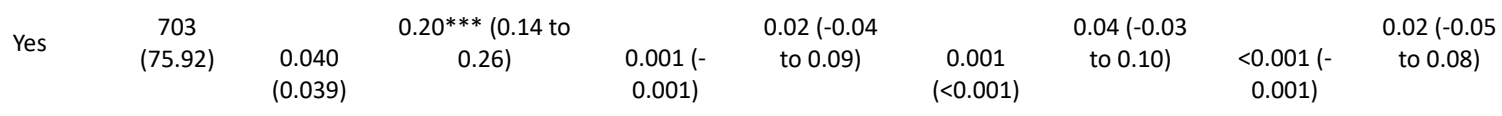




\begin{tabular}{cccccc}
\hline No & 223 & Ref. & Ref. & Ref. & Ref. \\
\hline
\end{tabular}

$* p<0.05 ; * * p<0.01 ; p<0.001$.

$\mathrm{AR}^{2}$, Adjusted R-Squared; Cl, confidence interval; N, number; Ref., reference.

${ }^{a}$ Posttraumatic stress symptoms were measured using the Impact of Event Scale-Revised (IES-R).

${ }^{\mathrm{b}}$ Depression, Anxiety and Stress were measured using the Depression Anxiety Stress Scale (DASS-21). 